\title{
Parameterization and quantification of recharge in crystalline fractured bedrocks in Galicia-Costa (NW Spain)
}

\author{
J. R. Raposo ${ }^{1}$, J. Molinero ${ }^{2}$, and J. Dafonte ${ }^{1}$ \\ ${ }^{1}$ Escola Politécnica Superior, University of Santiago de Compostela, Campus Universitario s/n, 27002 Lugo, Spain \\ ${ }^{2}$ Amphos XXI, Passeig de Garcia i Faria, 49-51, 1o-1a, 08019 Barcelona, Spain
}

Correspondence to: J. R. Raposo (juanramon.raposo@usc.es)

Received: 20 January 2012 - Published in Hydrol. Earth Syst. Sci. Discuss.: 13 February 2012

Revised: 18 May 2012 - Accepted: 22 May 2012 - Published: 15 June 2012

\begin{abstract}
Quantifying groundwater recharge in crystalline rocks presents great difficulties due to the high heterogeneity of the underground medium (mainly, due to heterogeneity in fracture network, which determines hydraulic parameters of the bedrock like hydraulic conductivity or effective porosity). Traditionally these rocks have been considered to have very low permeability, and their groundwater resources have usually been neglected; however, they can be of local importance when the bedrock presents a net of well-developed fractures. The current European Water Framework Directive requires an efficient management of all groundwater resources; this begins with a proper knowledge of the aquifer and accurate recharge estimation. In this study, an assessment of groundwater resources in the Spanish hydrologic district of Galicia-Costa, dominated by granitic and metasedimentary rocks, was carried out. A water-balance modeling approach was used for estimating recharge rates in nine pilot catchments representatives of both geologic materials. These results were cross-validated with an independent technique, i.e. the chloride mass balance (CMB). A relation among groundwater recharge and annual precipitation according to two different logistic curves was found for both granites and metasedimentary rocks, thus allowing the parameterization of recharge by means of only a few hydrogeological parameters. Total groundwater resources in Galicia-Costa were estimated to be $4427 \mathrm{hm}^{3} \mathrm{yr}^{-1}$. An analysis of spatial and temporal variability of recharge was also carried out.
\end{abstract}

\section{Introduction}

Groundwater is an important source of potable drinking water. Worldwide $50 \%$ of the municipal water supplies come from groundwater. In general, groundwater is particularly important as a source of drinking water for rural and dispersed populations (Fornés et al., 2005).

Since the 1950s and due to advances in drilling technology, groundwater use has experienced a remarkable growth, primarily as a result of the initiatives taken by thousands of individual users, farmers and small municipalities. The public sector has rarely participated in the planning, administration or control of these developments (Hernandez-Mora et al., 2001). It is significant that, in spite of its importance, groundwater continues to be a largely misunderstood and often neglected resource. In fact, some southern European countries lack good groundwater quality and quantity monitoring systems (Hernandez-Mora et al., 2001). If the prevailing anarchy continues, serious problems may appear in the mid or long-term. Some problems related to water table depletion, groundwater quality degradation, land subsidence, or ecological impacts on aquatic ecosystems are already well documented (Llamas and Martínez-Santos, 2005). Groundwater depletion is especially problematic in shallow aquifers where the drying up of shallow wells can directly occur; this mainly affects the water supply of people with less resources.

Subsequent to the approval of the European Water Framework Directive (WFD), water agencies are required to reach a good quantitative and qualitative state of conservation for all groundwater and surface water bodies (European Commission, 2000). For this aim, an initial characterization and knowledge of actual renewable resources is needed, 
including groundwater resources. Quantification of the rate of groundwater recharge is a basic prerequisite for efficient groundwater resource management. However, the rate of aquifer recharge is one of the most difficult components to measure when evaluating ground water resources (Sophocleous, 1991). For this reason, the development of new river basin management plans in accordance with the requirements of the WFD is a challenge for European water agencies.

The hydrologic district of Galicia-Costa is one of the 16 districts in which the Spanish Water Administration is divided. It covers all the watersheds completely located inside the Autonomous Region of Galicia (NW of Spain). In this district more than one quarter of the total population use groundwater resources through private water supply facilities, especially in the rural areas (Romay and Gañete, 2007). This use of groundwater occurs on the fringes of the public water supply by means of individual or communal private wells and spring water collecting. According to the Spanish Geologic Survey (IGME), there are more than 300000 wells in Galicia (Navarro Alvargonzález et al., 1993). All of these groundwater abstractions contrast with the minimal knowledge and study of the groundwater in Galicia. The granitic and metamorphic rocks that dominate the area of Galicia-Costa have traditionally been considered almost impervious or to have very low permeability, and their groundwater resources have usually been neglected in planning and water management. However, groundwater can become an important and volumetrically significant water store when the weathering and fracturing of the bedrock develop shallow aquifers (Neal and Kirchner, 2000). Several studies using various methodologies (water balance, chloride mass balance, flow hydrograph decomposition) in Northern Portugal (a region geologically and climatically similar to GaliciaCosta) estimate the groundwater recharge range to be $5 \%$ to $31 \%$ of precipitation (Alencoão et al., 2000; Lima and Silva, 1995; Martins Carbalho et al., 2000; Pereira, 2000). The few studies carried out in Galicia show that although the groundwater recharge rate is low, it is not negligible, especially taking into account the high precipitation rate in this region (900-2500 $\mathrm{mm} \mathrm{yr}^{-1}$ ). In a site study on granitic terrains the recharge was estimated to be $8.8 \%$ of the annual precipitation using a water balance model (Samper et al., 1997, 1999; Soriano and Samper, 2000). Using the same methodology, Raposo et al. (2010) estimates an average recharge at $13.6 \%$ of annual precipitation in five granitic catchments in Galicia-Costa. This wide range of recharge rates makes it difficult to carry out a regional characterization and quantification of groundwater resources. A new approach is needed to propose a regional recharge rate, different from the classical linear relationship of recharge-precipitation.

Besides in the neighboring North Portugal, aquifers with similar characteristics to Galician ones (developed on fractured crystalline bedrocks) are relatively frequent in Atlantic Europe: they are found in the Armorican and Central Massifs of France, Scotland, Wales and Cornwall (UK), Ireland and Scandinavia, (Environment Agency, 2005; Wendland et al., 2008; Knutsson, 2008; Robins, 2009; Banks et al., 2010). These regions are generally characterized by high precipitation, temperate-cold climatic conditions and a traditional use of shallow groundwater.

Recharge rate estimations in crystalline rock areas in Brittany, Scotland, Wales and the Channel Islands range between $15.4 \%$ and $40 \%$ of the precipitation (Robins and Smedley, 1998; Robins and Misstear, 2000; McCartney and HoughtonCarr, 1998; Robins et al., 2002; Church, 2004; Rouxel et al., 2011). Estimations in the Bohemian Massif are more than $20 \%$ of the mean annual precipitation (Krásný, 2002).

Crystalline rock aquifers are also exploited widely in tropical climates (Africa and India). There, however, the hydrogeological conditions are very different. These rocks are deeply weathered and rainfall recharge may be scarce. Granitic-gneissic complexes in southern India have a natural recharge rate of $3-15 \%$ of precipitation, partially because of the adverse hydrometeorological factors (Sukhija et al., 1996; Massuel et al., 2007). Similarly, estimations of groundwater recharge of shallow aquifer on crystalline rocks in West Africa are 5-12\% of precipitation (Martin and van de Giesen, 2005; Fouépé Takounjou et al., 2010).

An accurate characterization of aquifer recharge is crucial for efficient groundwater resource management. In addition, recent droughts in Galicia have highlighted the vulnerability of Galician groundwater resources due to variations in recharge, and have also emphasized the need for reliable estimates of groundwater recharge. The first attempt of a global estimation of groundwater resources in Galicia (Xunta de Galicia, 1991) established a criterion based on theoretical infiltration indexes for different terrains. The total renewable resources were estimated at $2000 \mathrm{hm}^{3} \mathrm{yr}^{-1}$ for all of Galicia. Using the hydrological model SIMPA, Estrela et al. (1999) elevated this estimation to $2234 \mathrm{hm}^{3} \mathrm{yr}^{-1}$ in Galicia-Costa only, which represents an average groundwater recharge of $18 \%$ of precipitation. The last study on this topic (Xunta de Galicia, 2011) highlighted the large uncertainty in the process of recharge quantification in Galicia-Costa due to the high heterogeneity of the medium, and used three different methodologies to estimate the renewable resources to be between a range of 3023 and $3689 \mathrm{hm}^{3} \mathrm{yr}^{-1}$.

Groundwater recharge to shallow unconfined aquifers is complex and is dependent upon the occurrence, intensity, and duration of precipitation, temperature, humidity and wind velocity, as well as the characteristics and thickness of the soil and rock above the water table, the surface topography, vegetation, and land use (Memon, 1995). Groundwater recharge shows significant spatial and temporal variability as a consequence of variations in climatic conditions, land use, irrigation and hydrogeological heterogeneity (Sharma, 1989). The heterogenic hydrogeological characteristics of Galicia-Costa (mainly due to the variable fracturing degree of the bedrock) require a different approach for recharge 
quantification and a more comprehensive study to take this variability into account.

Groundwater recharge can be quantified by different methods addressed at different hydrological zones to evaluate different timing of recharge, from potential values in the soil to some-delayed and smoothed net estimates in the saturated zone. Some approaches for recharge calculation are the water-table fluctuation method, seepage meters, lysimeters, isotopes, chloride mass balance (CMB) and different modeling approaches. Each technique has advantages and disadvantages, and choosing the appropriate method for a particular site and study is often difficult. Selection must be made based on different considerations: space/time scale factors, range, and the reliability of recharge estimates based on different techniques (Scanlon et al., 2002). Uncertainties in each approach to estimating recharge underscore the need for the application of multiple techniques to increase the reliability of recharge estimates (Scanlon et al., 2002). Ideally, as many different approaches as possible should be used to estimate recharge.

In this study, two independent methodologies were applied. Firstly, a hydrological model, based on watertable fluctuations and water-budget calculations using both surface-water and groundwater inputs, was used to estimate groundwater recharge to shallow aquifers. This hydrological model was applied to 9 small-size catchments ranged from 0.23 to $26.26 \mathrm{~km}^{2}$ representatives of the main geologies and climates existing in the Galicia-Costa district. Subsequently, a tracer technique (CMB) was used in order to cross-validate the results obtained by the principal methodology. The results obtained for these pilot catchments were finally extrapolated to the whole district by means of a GIS tool to assess the groundwater in Galicia-Costa. Extrapolation was carried out according to geological and climatic criteria.

Both water balance models and CMB are proper methods for a watershed or regional approach (Flint et al., 2002). While CMB presents the advantage of being a simple concept with few parameters needed, it also has several limitations such as assumptions not completely valid for fractured rocks or the high variability of $\mathrm{Cl}^{-}$deposition rate with time; these limitations increase the uncertainties of its results, for this reason $\mathrm{CMB}$ results are used only to compare with water balance model results. In contrast, limitations of water balance models, as equivalence of shallow infiltration and recharge (Flint et al., 2002), can be easily assumed for shallow aquifers present on fractured bedrock, while strengths as spatial and temporal distributions of recharge are desirable capabilities of the modeling approach. Furthermore, where land uses and soil types are relatively uniform and limited data determines the choice of model, simple models provide a reasonable basis for long-term recharge estimates at the catchment scale compared to complex distributed models (Bradford et al., 2002).

There are two major objectives in this study: first to quantify groundwater recharge in the two main geologies present in Galicia-Costa (granites and metasedimentary rocks) by using two different techniques, their comparison and the sensitivity and uncertainty analysis of the estimates; secondly, to globally assess the groundwater resources in GaliciaCosta by means of parameterization of recharge and its GISsupported extrapolation as well as the analysis of the spatial and temporal variability of the resource.

\section{Description of the study area}

The Galicia-Costa hydrologic district is located on the North West coast of Spain (Fig. 1). It contains all of the watersheds entirely located inside the Autonomous Region of Galicia and extends over $13072 \mathrm{~km}^{2}$, where more than 2000000 people are settled. This means $44 \%$ of the Galician territory and $75 \%$ of its population. Due to the existence of many small aquifers developed on fractured and weathered bedrock throughout the district and the difficulty of individually characterizing each separate aquifer, an aggregate approach was required for the study of the Galician hydrogeology. Accordingly, the whole territory was considered as a continuous groundwater body that must be protected. For a management purpose, the Galician Water Administration (Augas de Galicia) defined 18 groundwater bodies following geographic and topographic criteria rather than geologic criteria. The boundaries of each groundwater body coincide with the linked river watershed (Xunta de Galicia, 2003). These groundwater bodies really are the sum of a number of small disconnected aquifers.

The main sources of the high recharge heterogeneity existing in Galicia-Costa are the different geology, the bedrock fracturing degree and the hydroclimatological conditions.

From a geological standpoint, Galicia-Costa can be divided into two main blocks (IGME, 2004): granitic rocks occupy approximately $38 \%$ of the area, and metamorphic rocks (mainly slates, schist and gneisses) occupy $54 \%$ of the total area (the remaining area corresponds to water bodies, quaternary deposits and a minimal area of limestone). Both groups of rocks have traditionally been considered to have very low permeability. However, they are frequently highly fractured and weathered, thus allowing the storage of a considerable volume of water in the secondary porosity. As shown in Fig. 1, the bedrock presents a vast net of faults and fractures. Some areas are especially fractured (e.g. northern quartzites), while other rock units are basically fresh (e.g. the Ordes Complex in central Galicia).

The weathering front in crystalline rocks is not continuous and the thickness of the regolith differs from place to place. Generally, in lowland areas, valleys and highly fractured areas, the weathering depth varies from 5 to $20 \mathrm{~m}$ (Molinero Huguet et al., 1998; Wilson, 1998; Sequeira Braga et al., 2002); while in mountain and hilly areas, the superficial weathering cover is very thin $(<3 \mathrm{~m})$ (Samper et al., 2006). Similarly, the depth of fracturing crystalline rocks 


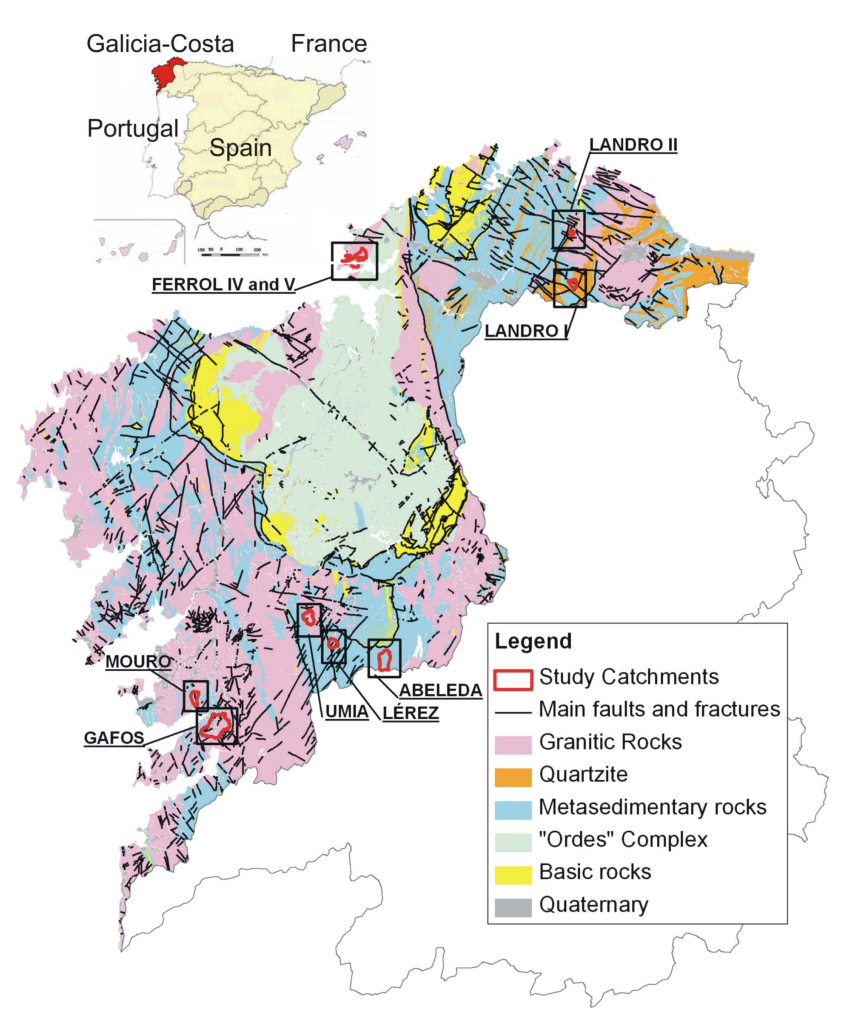

Fig. 1. Location of the hydrologic district of Galicia-Costa in the Spanish hydraulic division, the study catchments and geological map (elaborated from GEODE geological map; IGME, 2004).

varies significantly from site to site depending on the tectonic history of the rock. In a granitic site, Molinero Huguet et al. (1998) limit the rock with a high density of fractures to a depth of lower than $50 \mathrm{~m}$, whereas geophysical surveys in a schistose site reported depths of fractured rock within a range of 30 to $100 \mathrm{~m}$ (Dafonte and Raposo, 2009).

From the coast line to the mountainous inland in GaliciaCosta (Galician Dorsal) there is also a high gradient of temperatures, evapotranspiration and precipitation (900$2500 \mathrm{~mm} \mathrm{yr}^{-1}$ ). Because the Galician aquifers are highly rain-recharge dependent and the residence time of the water in these aquifers is very short (Soriano and Samper, 2000; Samper, 2003; Raposo et al., 2010), climate conditions are relevant in the determination of the amount of recharge.

Land cover in Galicia-Costa is characterized by forest and grassland mixed mosaics, with scattered small cultivation plots. Agriculture is mainly rain fed, therefore effects of irrigation on recharge can be neglected.

In order to characterize the aquifers in Galicia-Costa, nine lumped hydrological models were performed in small-size basins $\left(0.23-26.26 \mathrm{~km}^{2}\right)$. The different lumped models cover granitic, quartzite and metasedimentary rocks, in both coastal and inland areas, thus the different recharge rates in each condition can be analyzed.

\section{Hydrological model}

Visual Balan v2.0 (Samper et al., 2005) is a water balance model for the simultaneous modeling of daily water balances in the soil, in the unsaturated zone and in the aquifer that takes into account the main processes of water flow in underground media. Parameter optimization is conducted by calibrating against multiple targets, such as groundwater levels and stream flow rates. Inclusion of both surface water and groundwater as input data provides a framework that can be used to check continuity and better constrain model parameters and thus provides more reliable results than obtained only from surface-water data.

Visual Balan v2.0 is a lumped model and provides a single recharge estimate for the entire catchment, thus it can only be applied to small catchments and requires upscaling in order to cover an entire hydrologic district. On the other hand, small-scale applications allow more precise methods to be used to measure or estimate individual parameters of the water balance equation (Healy et al., 1989).

Visual Balan has proven reliable and robust when reproducing measured values of prolonged monitoring tasks that were carried out in several catchments of NW Spain (Martínez et al., 2006; Raposo et al., 2010; Samper et al., 1997, 1999; Sena and Molinero, 2009; Soriano and Samper, 2000), and for recharge evaluation in other regions of Spain and Latin America (Candela et al., 2009; Carrica, 2004; Castañeda and García-Vera, 2008; Espinha-Marques et al., 2011; Garcia-Santos and Marzol; 2005; Jiménez-Martínez et al., 2010; Samper and Pisani, 2009; Weinzettel et al., 2002).

This model presents the advantages of using data that can be easily measured or estimated with reasonable accuracy (Jiménez-Martínez et al., 2010). Unknown parameters are calibrated by comparing computed stream flows and/or piezometric heads to measured data. The main input variables are daily temperature, precipitation, wind velocity, sunshine duration, relative humidity, and underground media parameters (i.e., soil thickness, porosity, field capacity, wilting point, hydraulic conductivity, curve number and recession and storage coefficients). The outputs of the model are the water balance components (runoff, interflow, vegetal interception, $\mathrm{ET}_{\mathrm{a}}$ and groundwater recharge) and the modeled groundwater levels and/or stream discharge rates.

According to Samper et al. (2005) there are three different regions in underground media: (1) the edaphic soil, where flow is mainly vertical and there is infiltration of rainfall and irrigation water, as well as evaporation and transpiration processes, etc.; (2) the unsaturated or vadose zone, where vertical (percolation) and horizontal flows (interflow) coexist; and (3) the aquifer, or saturated zone, that may have discharge flows such as springs and streams. Figure 2 shows the conceptual model for water flow between these three components. 


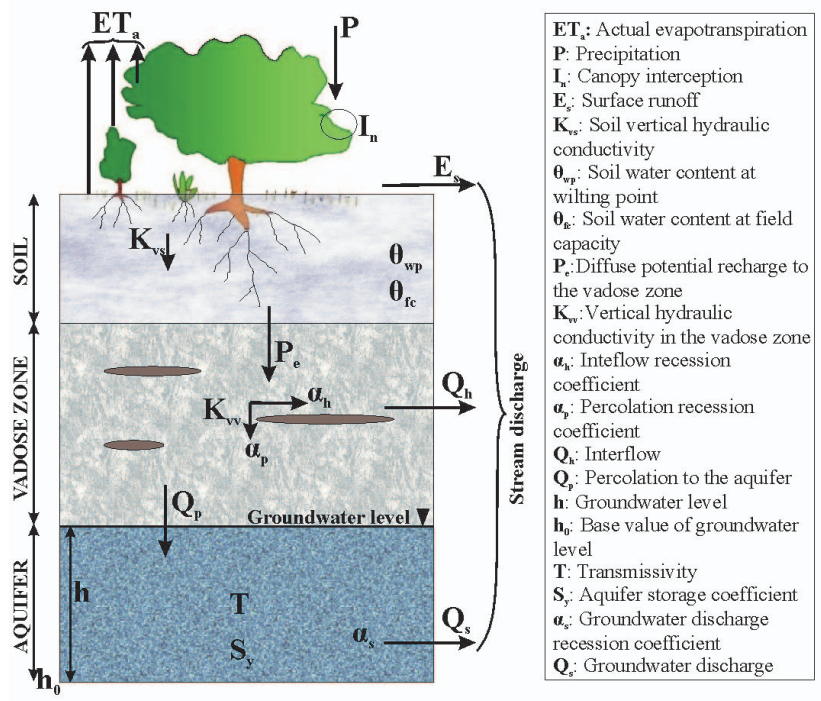

Fig. 2. Main components of water balance considered under the framework of the computer program Visual Balan (Samper et al., 2005).

\subsection{Soil water balance component}

The water balance in soil is represented by

$P+I_{r}-I_{n}-E_{\mathrm{s}}-\mathrm{ET}_{\mathrm{a}}-P_{e}=\Delta \theta$

where $P$ represents precipitation, $I_{r}$ is irrigation, $I_{n}$ is canopy interception, $E_{\mathrm{S}}$ is runoff, $\mathrm{ET}_{\mathrm{a}}$ represents the actual evapotranspiration, $P_{e}$ is potential recharge to the vadose zone and $\Delta \theta$ is the variation of soil water storage. Each component is expressed as cumulative water volume per surface unit during a time interval $\Delta t$ (in this study $\Delta t$ equals one day, and the unit is $\mathrm{mm}$ ). Because there are no significant irrigated areas, the present study considered daily precipitation as the only inflow of water in the balance. Further, this approach assumes a sequential model simulation for interception, runoff, evapotranspiration and the recharge process.

Canopy interception $\left(I_{n}\right)$ is the fraction of precipitation intercepted by vegetation (e.g. leaves, branches, stems and trunks). It was derived from Horton's (1919) empirical formula that describes a linear relationship between intercepted volume $\left(I_{n}\right)$ and total precipitation on vegetation $\left(P_{d}\right)$ in a rainfall event:

$$
\begin{array}{lll}
I_{n}=S_{d}+\gamma \times P_{d} & \text { if } & P_{d}>\frac{S_{d}}{1-\gamma} \\
I_{n}=P_{d} & \text { if } & P_{d} \leq \frac{S_{d}}{1-\gamma}
\end{array}
$$

where $S_{d}$ and $\gamma$ are empirical parameters related to the type of vegetation and plant height.

The surface runoff estimation $\left(E_{\mathrm{s}}\right)$ is derived from the curve number method (Soil Conservation Service, 1986), which is based on the relations between water losses and precipitation. Before runoff occurs, a precipitation threshold $\left(P_{\mathrm{o}}\right)$ due to interception, infiltration and superficial storage reduces the precipitation available for runoff to $P-P_{o} . P_{\mathrm{o}}$ can be empirically obtained as a function of tabulated values of curve number and $E_{\mathrm{S}}$ is calculated according to

$E_{\mathrm{S}}=\frac{\left(P-P_{\mathrm{o}}\right)^{2}}{P+4 P_{\mathrm{o}}}$

Potential evapotranspiration (ETP) can be calculated by the hydrological model using different methods. The FAO Penman-Monteith method (Allen et al., 1998) was chosen for this study because it is the method which provides the most reliable estimations in all regions and climates. A relevant step for recharge estimation is an accurate determination of actual evapotranspiration $\left(\mathrm{ET}_{\mathrm{a}}\right)$, since it can be significantly below ETP for long periods of time during the dry season. The Penman-Grindley method (Samper et al., 2005) was used to relate $\mathrm{ET}_{\mathrm{a}}$ with ETP. The relation varies depending on whether the soil water deficit $\left(\theta_{\text {swd }}\right)$ is higher than a threshold value (CRPG):

$\mathrm{ET}_{\mathrm{a}}=W+\mathrm{CEPG} \times(\mathrm{ETP}-W) \quad$ if $\theta_{\mathrm{swd}}>\mathrm{CRPG}$

$\mathrm{ET}_{\mathrm{a}}=\mathrm{ETP} \quad$ if $\theta_{\text {swd }}<\mathrm{CRPG}$

In the above equation, $W$ represents the input water (available water), $\theta_{\mathrm{swd}}=\theta_{\mathrm{fc}}-\theta$, where $\theta_{\mathrm{fc}}$ is the soil water content at field capacity and $\theta$ the current soil-water content, CEPG is a factor between 0 and 1, and CRPG constitutes the hydric deficit limit value and ranges between 0 and field capacity minus soil water content at wilting point $\left(\theta_{\mathrm{fc}}-\theta_{\mathrm{wp}}\right)$. All parameters are expressed as equivalent height of water $(\mathrm{mm})$ during a time interval $\Delta t$.

The diffuse potential recharge to the vadose zone $\left(P_{e}\right)$ was computed by the following logistic function (Samper et al., 2005). It assumes that the soil is homogeneous and isotropic and that there is no direct recharge through soil cracks and preferential flow pathways:

$P_{e}=\frac{K_{\mathrm{vs}}}{1+\beta e^{-\frac{\theta}{\alpha}}}$

where $K_{\mathrm{vs}}$ is the soil vertical hydraulic conductivity in $\mathrm{mm} \mathrm{day}^{-1}$, given that $\alpha=\left(\Phi_{\mathrm{s}}-\theta_{\mathrm{fc}}\right) / 4$ and $\beta=e^{\left(2+\frac{\theta_{\mathrm{fc}}}{\alpha}\right)}$.

\subsection{Vadose zone water balance component}

Potential recharge $\left(P_{e}\right)$ constitutes the only entry of water to the vadose zone from the edaphic soil zone, while outputs of water can occur horizontally as interflow $\left(Q_{\mathrm{h}}\right)$ and vertically as percolation to the aquifer $\left(Q_{\mathrm{p}}\right)$, according to the following expressions:

$Q_{\mathrm{h}}=\alpha_{\mathrm{h}} \times V_{\mathrm{h}}$ 
$Q_{\mathrm{p}}=K_{\mathrm{vv}}+\alpha_{\mathrm{p}} \times V_{\mathrm{h}}$

where $V_{\mathrm{h}}$ is the water volume stored in the vadose zone (in $\mathrm{mm}), K_{\mathrm{vv}}$ is the vertical hydraulic conductivity in the vadose zone (in mm day ${ }^{-1}$ ), $\alpha_{\mathrm{h}}$ and $\alpha_{\mathrm{p}}$ are recession coefficients for interflow and percolation (in day ${ }^{-1}$ ). Conceptually, interflow is related to the presence of perched aquifers in the vadose zone and $\alpha_{\mathrm{h}}$ depends on the average terrain slope, the distance traveled by the interflow along the hillside, the horizontal hydraulic conductivity and the drainable porosity in the vadose zone; $\alpha_{\mathrm{p}}$ is related with the distance between the perched level and the regional groundwater level, the vertical hydraulic conductivity and the drainable porosity in the vadose zone. An explicit scheme (Samper et al., 2005) was applied for solving water balance in the vadose zone.

\subsection{Aquifer water balance component}

As Visual Balan is a lumped model, water balance in the aquifer was solved by considering each catchment as a single cell, where water inputs and outputs determine the oscillation of the groundwater level at each $\Delta t$. This simplification can be assumed by taking into account the small size of pilot catchments considered in this study. The only entry of water to the aquifer from the vadose zone (that links both underground media) is the vertical percolation $\left(Q_{\mathrm{p}}\right)$, while groundwater discharge $\left(Q_{\mathrm{s}}\right)$ represent the only output. The aquifer balance Eq. (8) relates these inputs and outputs with the variation of the stored water volume $\left(\Delta V_{\mathrm{a}}\right)$ :

$$
\left(Q_{\mathrm{p}}-Q_{\mathrm{s}}\right) \Delta t=\Delta V_{\mathrm{a}}
$$

The greater the water volume stored in the aquifer, the greater the groundwater discharge is, proportionally to a discharge recession coefficient $\left(\alpha_{\mathrm{s}}\right)$ :

$Q_{\mathrm{s}}=\alpha_{\mathrm{s}} \times \Delta V_{\mathrm{a}}$

The water volume in the aquifer $\left(V_{\mathrm{a}}\right)$ and the groundwater level $(h)$ are referred to as a base value $\left(h_{\mathrm{o}}\right)$, which corresponds to a volume $V_{\text {ao }}$. The water volume stored over the base value, $\Delta V_{\mathrm{a}}=\left(V_{\mathrm{a}}-V_{\mathrm{ao}}\right)$, is related to the change of level $\Delta h=\left(h-h_{\mathrm{o}}\right)$ through the storage coefficient of the aquifer $\left(S_{y}\right)$ :

$\Delta V_{\mathrm{a}}=S_{y} \times \Delta h$

The model calculates on a daily basis the water level and the water stored volume in the aquifer; this allows a comparison between measured and simulated groundwater levels. Similarly, daily measured discharges in streams can be compared to those calculated by the model as the sum of surface runoff $\left(E_{\mathrm{s}}\right)$, interflow $\left(Q_{\mathrm{h}}\right)$ and groundwater discharge $\left(Q_{\mathrm{s}}\right)$.

\section{Chloride Mass Balance (CMB)}

The climatic component in groundwater chemical composition (Custodio, 1997; Murphy et al., 1996) is a function of the average chemical composition of precipitation. An accurate knowledge of this component allows explaining the presence of some ions in the groundwater and also can be used to estimate the average groundwater recharge by means of the mass balance of chemical components with a rainfall origin (Allison and Hughes, 1983; Rosenthal, 1987).

The chloride ion $\left(\mathrm{Cl}^{-}\right)$is ideal to perform chemical balances because it remains inert during the recharge process (there is no significant long-term exchange with the environment) and, unlike water, it remains in the soil after evapotranspiration processes. It is also highly soluble and usually has a known marine origin. This technique was widely used, both in the vadose zone and in the saturated-zone (Cook and Böhlke, 2000; Eriksson and Khunakasem, 1969; Sami and Hughes, 1996; Wood and Sanford, 1995). This study uses the CMB approach to evaluate the direct rainfall recharge, using sampling from the saturated-zone. The CMB approach spatially integrates recharge over areas upgradient from the measurement point. However, problems with extrapolating point-source data to determine spatial variability of recharge remain. For that reason the specific results obtained by this technique will be mainly used for comparison with the hydrological model results.

The mass of $\mathrm{Cl}^{-}$deposition into the system is the sum of wet deposition dissolved with precipitation and dry fallout, while runoff and groundwater recharge constitute the system outputs:

$P \times \mathrm{Cp}=R \times \mathrm{Caq}+I \times \mathrm{C} i$

where $R$ is the average net recharge $\left(\mathrm{mm} \mathrm{yr}^{-1}\right) ; P$ represents average annual precipitation $\left(\mathrm{mm} \mathrm{yr}^{-1}\right) ; I$ is the average runoff (overland and interflow); $\mathrm{Cp}$ is the effective average $\mathrm{Cl}^{-}$concentration in precipitation $\left(\mathrm{mg} \mathrm{l}^{-1}\right)$, including the contribution from dry fallout; Caq is the measured $\mathrm{Cl}^{-}$ concentration in groundwater $\left(\mathrm{mg} \mathrm{l}^{-1}\right)$; and $\mathrm{C} i$ is the average $\mathrm{Cl}^{-}$concentration in runoff and interflow $\left(\mathrm{mgl}^{-1}\right)$.

A zero surface runoff assumption is usually made for arid and semiarid climates, which simplifies the Eq. (11). However, although substantial surface runoff does not often occur in Galicia due to the high permeability of sandy soils, runoff can concentrate in washes or flows laterally along the soil/bedrock interface at the base of side slopes as interflow, which cannot be neglected. In humid climates the overestimation of recharge due to ignoring the chloride contribution by runoff and interflow may reach $50 \%$ of the estimation (Alcalá and Custodio, 2008b).

Due to the lack of chloride concentration data in runoff, a concentration factor $(\mathrm{Fc})$ for calculating the chloride concentration in runoff from chloride concentration in rainfall can be used. According to Prych (1998) Fc is only slightly above 1 in humid climates. In Northern Spain, González-Arias et 
al. (2000) calculated an Fc between 1 and 2, while Alcalá (2005) restricted its range to between 1 and 1.5 and provided only one Fc data for Galicia-Costa equal to 1.17. Assuming a homogenous concentration factor for the entire Galicia-Costa, groundwater recharge can be calculated as the following:

$R=(P-I \times \mathrm{Fc}) \times \frac{\mathrm{Cp}}{\mathrm{Caq}}$

This method appears to be valid for a first approximation of recharge in Galicia-Costa, as judged by its consistency with most other data sets discussed in this paper.

\section{Data compilation and model setup}

Model calibration was based on water monitoring data obtained at discharge gauges stations and wells within the study area. There is at least one well or a gauge station at the watershed outlet for each pilot catchment (Fig. 3). Where both water data are available a more accurate calibration can be carried out. Water table data were measured in wells on a weekly basis. The most practical and most commonly used method of measuring the discharge of a stream is the velocity-area method (World Meteorological Organization, 1980). Stream water velocity was measured on a weekly basis using a mini current meter. A stage-discharge relationship was developed for each gauge station. Most of the streams were monitored with automatic water-level pressure sensors that collect data on a 10-min basis in order to calculate continuous stream discharge. Daily average stream discharges were aggregated from 10-min data.

Daily precipitation, average air temperature, daily sunshine duration, relative humidity, wind speed and relationship between diurnal and nocturnal wind are the climate data required by the models. For this study, the historical climate inputs were obtained from 8 weather stations located in or close the studied catchments (Penedo do Galo, Muras, Fragavella, CIS-Ferrol, Pereiro, Mouriscade, Monte Castrove and Lourizan). All of them belong to the weather station network of Meteogalicia (Galician Meteorological Service), with the exception of the Muras weather station belonging to the University of Santiago de Compostela and placed specifically for this study. Missing data in the historical records were filled by linear correlations from the nearest complete weather stations using statistical regressions. The missing data were estimated from the data of the closest complete station, and were adjusted by the ratio of the long-term means for the whole historical series. The map of average precipitation in Galicia-Costa (Fig. 3) was built with the data from the Hydrological Plan of Galicia-Costa using 151 pluviometric stations (Xunta de Galicia, 2003).

An initial value of model parameters was obtained by either field measurements (i.e., soil thickness), bibliography (i.e., hydraulic conductivity, porosity, field capacity and

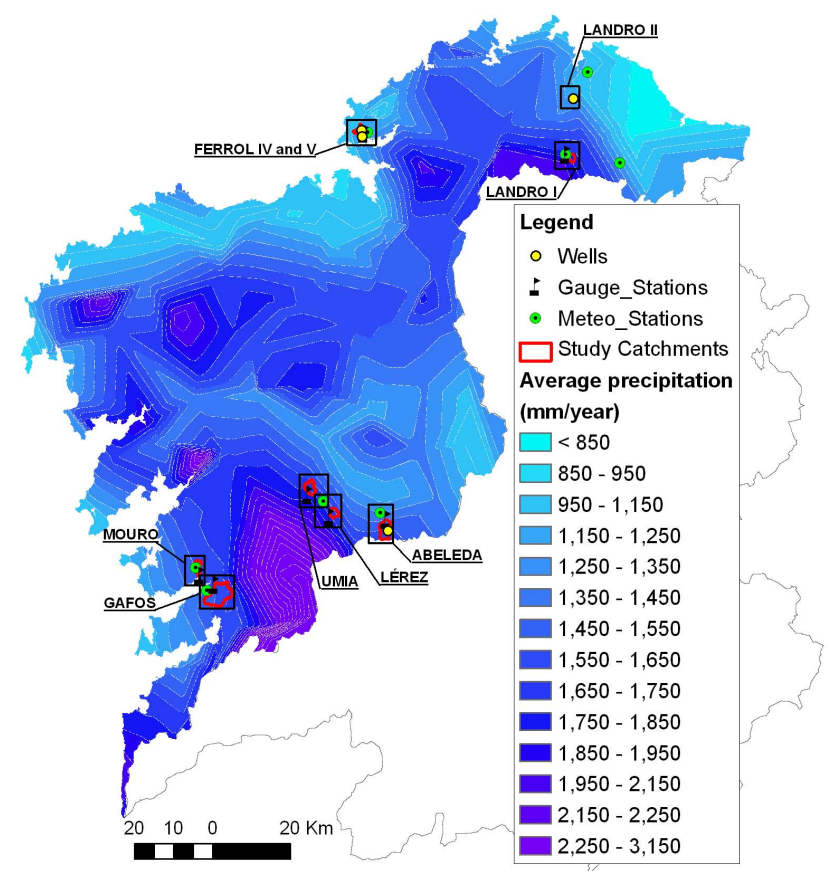

Fig. 3. Location of weather stations, wells and discharge gauge stations used for modeling the study catchments, and average precipitation map for Galicia-Costa built with data from Hydrological Plan of Galicia-Costa (Xunta de Galicia, 2003).

wilting point) (Barral et al., 1998; López et al., 1998; PazGonzález et al., 2001, 2003), tabulated data (i.e. curve number) (Soil Conservation Service, 1986) or values used for other close and similar catchments (i.e., recession and storage coefficients) (Samper et al., 1997, 1999; Soriano and Samper, 2000).

\section{Model calibration and results}

Visual Balan includes an automated calibration procedure based on Powell's method of multidimensional minimization (Press et al., 1989).

The calibration process consists of an initial autocalibration of the most sensible parameters with a starting point of the initial range of values recommended by bibliography or used in similar catchments. Finally, a more accurate manual calibration based on knowledge of the hydrogeological behavior of the catchments was performed.

There is a positive gradient between precipitation and altitude on the Southwest coast of Galicia due to a rise of precipitation induced by orographic lift, whereas a rain shadow effect is observed from the coastal mountain range to the inland areas (Carballeira et al., 1983). Due to this Foehn effect, Pereiro weather station collects a lower amount of precipitation compared to the Umia catchment, and therefore measured rainfall is not completely representative for the Umia 
(A)
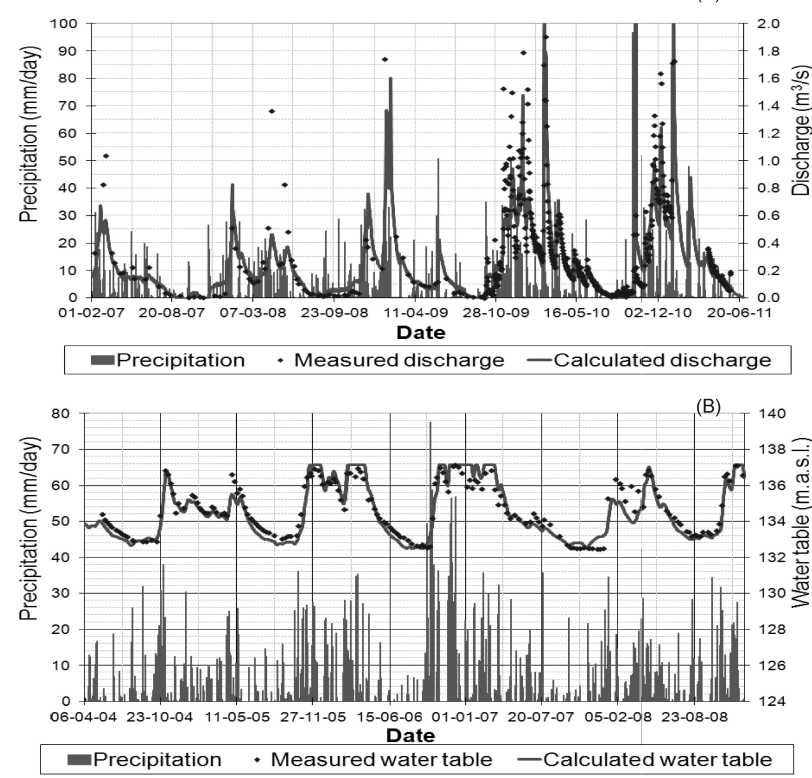

Fig. 4. Modeled versus measured flow rates in Abeleda Catchment (A) and modeled versus measured water table levels in Ferrol V Catchment (B).

model. A correction factor of 1.1 was applied for correcting gauged rainfall, according to the observed precipitation gradient for this location (Fig. 3).

The main parameters changed during the calibration process were: soil thickness, soil hydraulic conductivity, the percolation, interflow and aquifer recession coefficients, curve number and the aquifer storage coefficient (Table 1). However, they still remain in acceptable ranges according to bibliographic values for similar terrains in the region (Soriano and Samper, 2000; Franco Bastianelli, 2010).

Visual Balan models can be calibrated using water table series, discharge series or both types of data. The calibration criterion used in each catchment is shown in Table 2. Aquifer storage coefficient is only used by the model when water table data is available (i.e., Abeleda, Ferrol IV, Ferrol V and Landro II catchments). For the remaining catchments the aquifer storage coefficient cannot be computed, because the groundwater component of the model does not use this parameter for discharge calculations.

Figure 4 shows the accordance obtained for modeled versus measured flow rates and water table levels in two of the study catchments. The water level plateau in Fig. $4 \mathrm{~b}$ corresponds with the terrain surface. Water table in Ferrol V catchment is usually close to surface. During very rainy winters (like the period from 2005-2007), the water table almost reaches the terrain surface and soil saturation and ponding occurs occasionally. When the water table reaches the terrain surface, infiltration dramatically decreases and the model forces all the new water inputs to flow as run-off.
A validation process was not carried out for two reasons: firstly, a validation is not strictly necessary as no predictions are made with the model and the model is mainly used to derive the relation between recharge and precipitation; and secondly, available historical data series (of water table and discharge rates) for the studied catchments are too short, therefore, they may not be divided into two significant periods (one for calibration and other for validation).

According to Winter (2001), climate, topography and the geologic framework are the three main factors in the hydrologic landscape that control water flow. Rainfall supplies the land surface with water, the soil allows the water to infiltrate into the water table, and the geologic framework provides the permeability necessary for deeper flow. If the climatic and soil conditions allow recharge to reach the water table at a rate greater than the saturated zone can transmit the recharge away, then the permeability of the geologic framework controls the recharge rate. In this situation the underground water storage backs up to the point that excess infiltration is diverted overland, thus leading to a relatively shallow water table. In regions with relatively humid climate or low topographic relief, the geologic framework controls the rate of recharge (Sanford, 2002). These are the conditions present in Galicia, with high average precipitation and thin soils with relatively high permeability, and the groundwater recharge is usually limited by the permeability and storage capacity of deep fractured bedrock. As a result of these conditions, water balance is usually dominated by interflow that flows laterally along the soil/bedrock interface.

In fact, it is not possible to establish a good relationship between groundwater recharge and annual precipitation; the percentage of recharge varies in this study from $13.7 \%$ to $38.6 \%$ depending on the catchment (Table 2). The same conclusion was reached in studies carried out in similar aquifers in northern Portugal, where recharge varied widely from $1 \%$ to $44 \%$ depending on the catchment (Alencoão et al., 2000; Da Silva Lima and Oliveira da Silva, 2000; Marques da Costa, 2000; Martins Carbalho et al., 2000; Mendes Oliveira and Lobo Ferreira, 2000; Pereira, 2000). The addition of geological criteria, reflecting the significant influence of the geologic framework on groundwater recharge, is clearly necessary.

The statistical criteria used to evaluate the hydrologic goodness of fit were the coefficient of determination $\left(R^{2}\right)$ and the model efficiency or Nash-Sutcliffe coefficient $(E)$ (Nash and Sutcliffe, 1970). Both coefficients are highly affected by good matching records of high values. Errors in discharge measurement increase substantially during floods. As the main goal of this study is to evaluate the groundwater recharge responsible for the stream base flow, the relative Nash-Sutcliffe efficiency criteria $\left(E_{\text {rel }}\right)$ was also used for a more sensitive assessment during low flow conditions (Krause et al., 2005). The coefficient of determination for observed versus predicted daily stream flow in the different studied basins ranged from 0.74 to 0.98 . The model 
Table 1. Main parameters changed during the calibration process of the hydrological model and UTM coordinates of watersheds outlets.

\begin{tabular}{|c|c|c|c|c|c|c|c|c|c|}
\hline Parameter & Gafos & Lérez & Abeleda & Ferrol IV & Ferrol V & Landro I & Landro II & Umia & Mouro \\
\hline Soil thickness (m) & 1.43 & 0.65 & 0.65 & 1.61 & 1.50 & 0.60 & 1.61 & 2.02 & 1.10 \\
\hline Hydraulic conductivity $\left(K_{\mathrm{vs}}\right)\left(\mathrm{mm} \mathrm{h}^{-1}\right)$ & 7.20 & 18.18 & 6.84 & 4.41 & 6.84 & 10.01 & 9.49 & 5.06 & 3.54 \\
\hline Percolation recession coeff. $\left(\alpha_{\mathrm{p}}\right)\left(\right.$ day $\left.^{-1}\right)$ & 0.2476 & 0.2887 & 0.071 & 0.0397 & 0.6931 & 0.5915 & 0.2456 & 0.6125 & 0.7461 \\
\hline Interflow recession coeff. $\left(\alpha_{\mathrm{h}}\right)\left(\right.$ day $\left.^{-1}\right)$ & 0.4621 & 0.3151 & 0.271 & 0.287 & 0.6301 & 0.2175 & 0.5509 & 0.3587 & 0.5776 \\
\hline Aquifer recession coeff. $\left(\alpha_{\mathrm{s}}\right)\left(\right.$ day $\left.^{-1}\right)$ & 0.0277 & 0.062 & 0.03843 & 0.07749 & 0.0866 & 0.0184 & 0.009 & 0.2376 & 0.04067 \\
\hline Aquifer storage coeff. $\left(S_{y}\right)$ & - & - & 0.01302 & 0.002664 & 0.00276 & - & 0.0051 & - & - \\
\hline Curve number & 55 & 55 & 55.2 & 60.3 & 56 & 55 & 60 & 40 & 44.15 \\
\hline UTM-X* & 529424 & 557706 & 572784 & 559523 & 554284 & 611800 & 612608 & 551998 & 525630 \\
\hline UTM-Y* & 4697051 & 4719160 & 4716860 & 4815354 & 4813489 & 4813896 & 4828403 & 4721740 & 4699058 \\
\hline Basin area $\left(\mathrm{km}^{2}\right)$ & 26.26 & 6.23 & 9.88 & 2.18 & 0.32 & 3.20 & 0.47 & 6.88 & 3.67 \\
\hline Dominant geology & Granites & Schist & Schist & Granites & Granites & $\begin{array}{l}\text { Granites/ } \\
\text { Quartzite }\end{array}$ & Granites & Granites & $\begin{array}{l}\text { Gneisses/ } \\
\text { Schist }\end{array}$ \\
\hline
\end{tabular}

* Projected Coordinate System: WGS 1984 UTM, Zone $29^{\circ}$ N.

efficiency ranged from 0.70 to 0.82 . A better fit was obtained during low flow rates, as shown by the Relative NashSutcliffe index with a range of 0.76 to 0.87 (Table 2). In this study, two main geological blocks with different hydrogeological behavior were considered in Galicia-Costa: (a) quartzite and granitic rocks; and (b) metasedimentary rocks (slates, schists and gneisses). Although quartzite is a metamorphic rock, from a hydrogeological point of view and for the purposes of this study, it is considered to be more similar to granites due to its weathering products and high bedrock fracturing degree that favors greater water storage capacities. On the contrary, Galician schist and slates usually have closed fractures at high depth (Samper, 2003) and thus their aquifer storage capacity is filled quickly during high precipitation.

When all available recharge estimations in Galicia and Northern Portugal are plotted distinguishing the hydrogeology framework (Fig. 5), a clear relationship is observed $\left(R^{2}>0.9\right)$. Groundwater recharge increases with precipitation according to a logistic curve, but the recharge threshold and growing rate are clearly different. The small thickness of soil usually present on schists (except in the "Ordes" Complex) favors groundwater recharge even during low rainfall, while in the same conditions the deeper soil that may form in granite terrains favors evapotranspiration. An asymptotic limit due to the aquifer storage capacity is also observed (Alencoão et al., 2000). This limit is higher in granitic and quartzitic aquifers than in metasedimentary aquifers due to the greater secondary permeability observed in granites and quartzite versus slates, schists and gneisses. Therefore, granite formations are more interesting for groundwater purposes in areas with high precipitation, while schists are better under moderate rainfall conditions.

Temporal variability of groundwater recharge was obtained for the nine pilot catchments, based on the daily water balance model. Distribution of groundwater recharge throughout the year is strongly dependent on rainfall and presents only minor differences depending on the geological

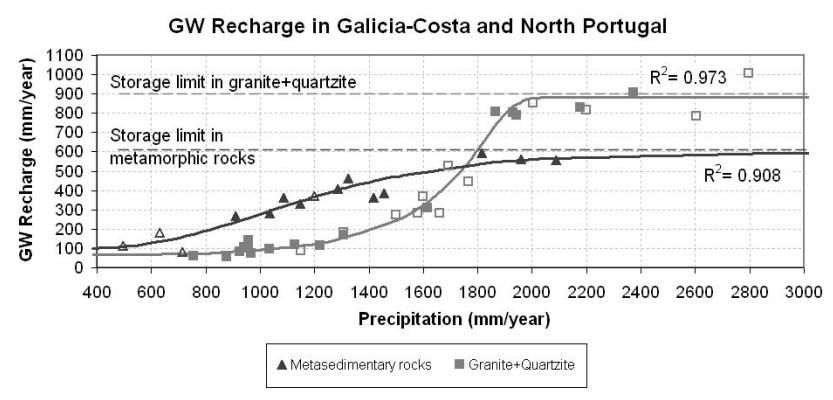

Fig. 5. Relationship between groundwater recharge and precipitation, depending on the geology. Filled symbols correspond with data gathered in Galicia-Costa area; other data were gathered from catchments in the nearby Northern Portugal.

framework, following a similar pattern to precipitations. $74 \%$ of groundwater recharge is concentrated in the first six months of the hydrologic year, while during the summer (July, August and September) only $6.7 \%$ of the total recharge occurs (Fig. 6).

The unequal temporal distribution of rainfall and groundwater recharge, in combination with the limited storage capacity of fractured bedrock aquifers (average storage coefficient equal to 0.0059) and the short residence time of groundwater in them (average recession coefficient equal to $0.066 \mathrm{day}^{-1}$ and average time of semi-depletion of groundwater discharge equals to 22.85 days) reduces the availability to develop this resource to supply big cities.

\section{Chloride mass balance results}

Strong spatial variability in chloride deposition in coastal areas is one difficulty encountered in appropriately applying the CMB method. Coastal distance appears to be the most significant factor controlling chloride deposition in the study area; it can reach up to $70 \%$ of the spatial variability in chloride deposition (Guan et al., 2010). 
Table 2. Results and evaluation of the hydrologic goodness of fit in the studied catchments.

\begin{tabular}{|c|c|c|c|c|c|c|c|c|c|}
\hline Basin (calibration criteria) & $\begin{array}{l}\text { Gafos } \\
\text { (discharge) }\end{array}$ & $\begin{array}{l}\text { Lérez } \\
\text { (discharge) }\end{array}$ & $\begin{array}{l}\text { Abeleda } \\
\text { (discharge/ } \\
\text { water-table) }\end{array}$ & $\begin{array}{l}\text { Ferrol IV } \\
\text { (discharge/ } \\
\text { water-table) }\end{array}$ & $\begin{array}{l}\text { Ferrol V } \\
\text { (water-table) }\end{array}$ & $\begin{array}{l}\text { Landro I } \\
\text { (discharge) }\end{array}$ & $\begin{array}{l}\text { Landro II } \\
\text { (water-table) }\end{array}$ & $\begin{array}{l}\text { Umia } \\
\text { (discharge) }\end{array}$ & $\begin{array}{l}\text { Mouro } \\
\text { (discharge) }\end{array}$ \\
\hline Average precipitation $\left(\mathrm{mm} \mathrm{yr}^{-1}\right)$ & 1488 & 1598 & 1183 & 1254 & 1250 & 2029 & 1022 & 1996 & 2089 \\
\hline $\mathrm{ET}_{\mathrm{a}}(\% P)$ & $22.5 \%$ & $10.6 \%$ & $21.1 \%$ & $37.5 \%$ & $31.5 \%$ & $21.9 \%$ & $31.3 \%$ & $14.2 \%$ & $17.8 \%$ \\
\hline Groundwater Recharge ( $\% P$ ) & $15.9 \%$ & $32.1 \%$ & $27.2 \%$ & $15.0 \%$ & $16.8 \%$ & $40.9 \%$ & $9.1 \%$ & $42.1 \%$ & $25.5 \%$ \\
\hline Run-off $(\% P)$ & $11.0 \%$ & $9.3 \%$ & $3.7 \%$ & $6.8 \%$ & $3.8 \%$ & $11.6 \%$ & $2.7 \%$ & $0.02 \%$ & $5.1 \%$ \\
\hline Interflow $(\% P)$ & $42.7 \%$ & $41.6 \%$ & $41.3 \%$ & $31.6 \%$ & $41.2 \%$ & $19.2 \%$ & $46.1 \%$ & $38.5 \%$ & $42.7 \%$ \\
\hline Rainfall interception (\%P) & $7.9 \%$ & $6.4 \%$ & $6.7 \%$ & $9.1 \%$ & $6.8 \%$ & $6.4 \%$ & $10.8 \%$ & $6.2 \%$ & $8.9 \%$ \\
\hline Coeff. $R^{2}$ & 0.8010 & 0.7413 & $\begin{array}{l}0.7646 / \\
0.7369\end{array}$ & $\begin{array}{l}0.8215 / \\
0.8025\end{array}$ & 0.8916 & 0.7850 & 0.9863 & 0.8579 & 0.7611 \\
\hline Nash-Sutcliffe & 0.7014 & 0.7138 & 0.7489 & 0.8174 & - & 0.7460 & - & 0.7961 & 0.8218 \\
\hline Relative Nash-Sutcliffe & 0.8530 & 0.8370 & 0.8480 & 0.7745 & - & 0.8732 & - & 0.8566 & 0.8185 \\
\hline
\end{tabular}

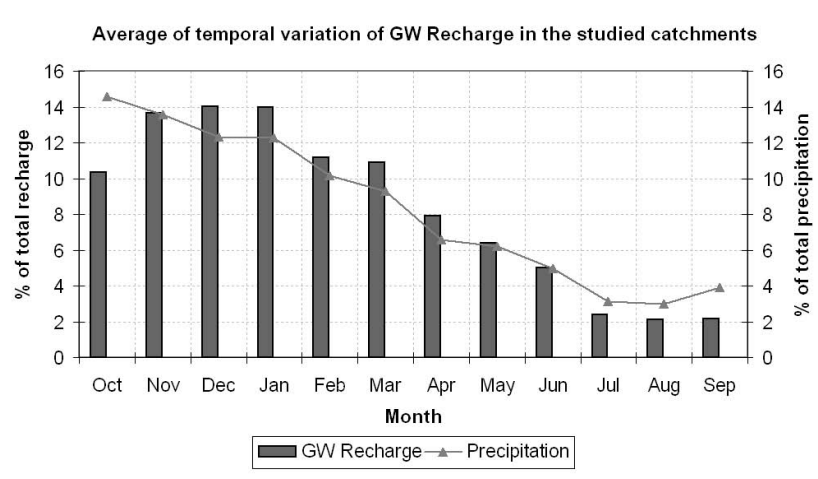

Fig. 6. Temporal variability of groundwater recharge: average percentage of monthly groundwater recharge and precipitation along the year in the nine pilot catchments.

In order to compute the CMB, a comprehensive bibliographic revision was carried out looking for historic data of chloride concentration in rainfall in Galicia (Alcalá and Custodio, 2008a; Fernández-Sanjurjo et al., 1997; García-Rodeja et al., 1998; Gómez Rey et al., 2002; Prada-Sanchez et al., 1993; Silva et al., 2007; Vázquez et al., 2003). In order to uniformly cover all of Galicia-Costa, 122 rainfall samples were collected and analyzed in 2008 (a year with average precipitation within the normal range for Galician climate) from 56 locations where no bibliographic data were available (Fig. 7a). Samples were preferably taken close to the basins where any hydrological models were performed, in order to compare the results. This sampling procedure consisted of directly gathering rainwater in portable collectors during different salient rainfall events and immediately transporting the samples to the laboratory in order to avoid any possible evaporation effects on the subsequent chloride concentration analysis. This procedure assumes that $\mathrm{Cl}^{-}$dry deposition is negligible due to the wet Galician climate and high frequency of rainfall events.

On the other hand, since 2007 groundwater chloride concentration has been analyzed on a bimonthly basis in 54 locations included in the groundwater quality network of Augas de Galicia (Fig. 7b). These chloride data were added to groundwater samples collected in a sole field study in 2006 and the available bibliographic data (Alcalá, 2005; Rodríguez Blanco et al., 2003).

An interpolation by the inverse distance weighted method of punctual chloride data in groundwater and rainfall was carried out using a GIS tool.

Groundwater chloride concentration follows a geographical and topographical pattern (Guan et al., 2010): maximum concentrations of chloride are found in coastal areas, while minimum concentrations are found in inland mountainous areas (Fig. 7b).

Assuming in this study an average runoff (overland plus interflow) equal to $44.57 \%$ of total precipitation (Table 2) and a homogeneous concentration factor equal to 1.17 (Alcalá, 2005), groundwater recharge was computed according to Eq. (12). Maximum groundwater recharge is reached in mountainous areas (e.g. Xistral, Suido and Testeiro Mountains) where high rainfall and high recharge rates converge (Fig. 7c).

A comparison of results was carried out wherever groundwater recharge was obtained by both methodologies (the hydrological model and the CMB) (Table 3). The consistency of these results confirms the validity of the computed groundwater recharge (Fig. 8).

\section{Global groundwater resource assessment in Galicia-Costa}

Reasonable estimates of recharge over extended areas can be derived using readily obtained field data without having to consider the complicating aspects of small-scale (local) variability (de Vries and Simmers, 2002). The combination of reliable local data and GIS technology offers promise for a better understanding and quantification of recharge over large areas (de Vries and Simmers, 2002).

A GIS tool, aimed at extrapolating the results obtained in all analyzed catchments, was used in the whole of GaliciaCosta. A geodatabase comprised of the main geological, geographical, meteorological and demographic data for the whole hydrologic district of Galicia-Costa was built. As a 

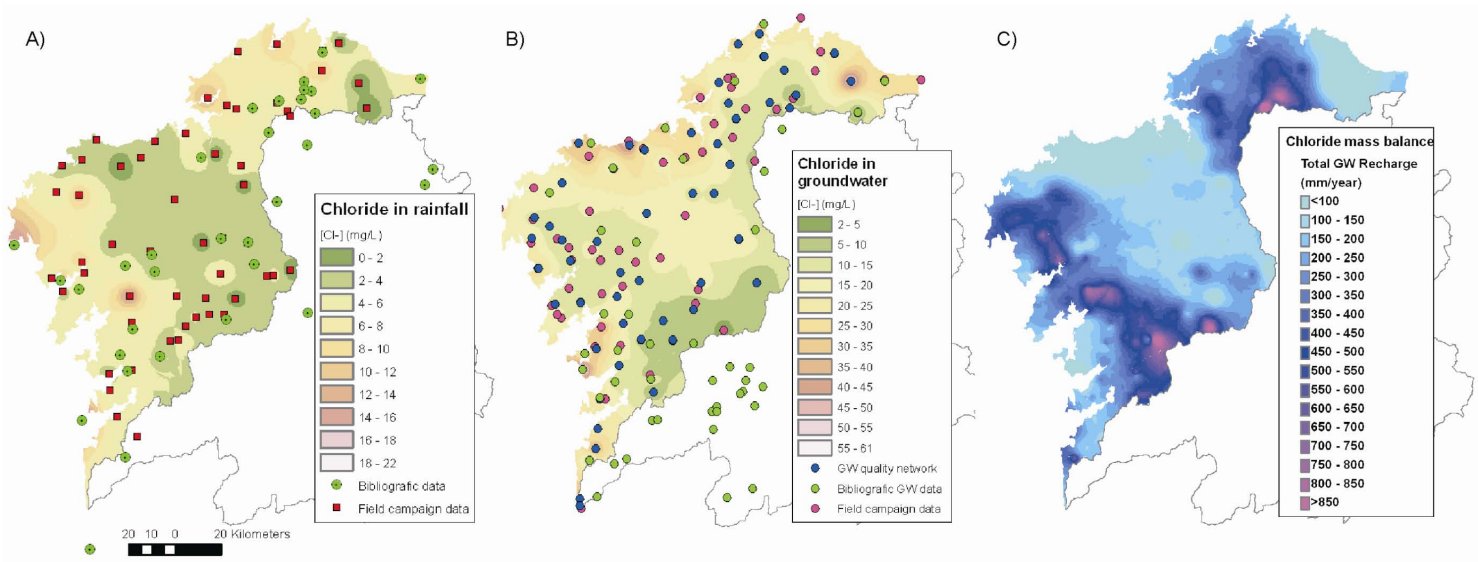

Fig. 7. Map of chloride concentration in rainfall (A), in groundwater (B), and groundwater recharge computed by chloride mass balance (C).

Table 3. Comparison of groundwater recharge computed by different methodologies.

\begin{tabular}{|c|c|c|c|c|c|}
\hline \multirow[b]{2}{*}{ Basin } & \multirow[b]{2}{*}{$\begin{array}{l}{\left[\mathrm{Cl}_{\text {rainfall }}^{-}\right]} \\
\left(\mathrm{mg} \mathrm{l}^{-1}\right)\end{array}$} & \multirow[b]{2}{*}{$\begin{array}{l}{\left[\mathrm{Cl}_{\mathrm{GW}}^{-}\right]} \\
\left(\mathrm{mg} \mathrm{l}^{-1}\right)\end{array}$} & \multirow[b]{2}{*}{$\begin{array}{l}\text { Interflow + runoff } \\
\text { (\%Precip.) }\end{array}$} & \multicolumn{2}{|c|}{ Recharge rate (\% precipitation) } \\
\hline & & & & $\begin{array}{l}\text { Chloride mass } \\
\text { balance }\end{array}$ & $\begin{array}{l}\text { Hydrological } \\
\text { model }\end{array}$ \\
\hline Ferrol IV+V & 12.54 & 35 & $41.65 \%$ & $18.37 \%$ & $15.9 \%$ \\
\hline Landro I & 5.51 & 7.88 & $30.8 \%$ & $44.77 \%$ & $40.9 \%$ \\
\hline Lérez & 4.47 & 6.03 & $50.9 \%$ & $29.98 \%$ & $32.1 \%$ \\
\hline Gafos & 4.21 & 12.39 & $53.7 \%$ & $12.63 \%$ & $15.9 \%$ \\
\hline Umia & 4.47 & 7.05 & $38.5 \%$ & $34.44 \%$ & $42.1 \%$ \\
\hline Landro II & 7.57 & 20.71 & $48.8 \%$ & $15.68 \%$ & $9.1 \%$ \\
\hline Mouro & 6.01 & 13.31 & $47.8 \%$ & $19.90 \%$ & $25.5 \%$ \\
\hline Valiñas & 3.42 & 13.32 & $45.9 \% *$ & $11.89 \%$ & $8.8 \% *$ \\
\hline
\end{tabular}

* Model data from (Samper et al., 1997).

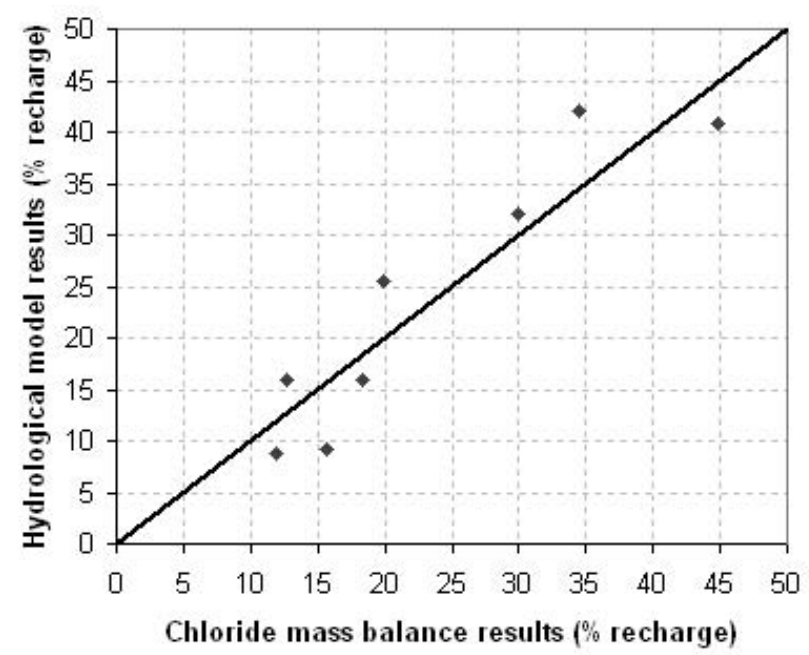

Fig. 8. Groundwater recharge computed by hydrological models versus chloride mass balance results. function of simplified geology, the district was divided into four main blocks that were assumed to have similar hydrogeological behavior (Fig. 9a). Based on the studies carried out using the hydrological models in the pilot catchments cross-validated with the $\mathrm{CMB}$, an equation as a function of annual precipitation was established to calculate the groundwater recharge for each one of the two main hydrogeological areas in Galicia-Costa: granites and quartzite (Eq. 13) and metasedimentary rocks (Eq. 14).

$$
\begin{aligned}
& \text { Recharge }=62.425+\frac{822.215}{\left(1+11.44 \times e^{-0.0264 \times P+47.98}\right)^{0.139}} \\
& \text { Recharge }=88.425+\frac{505.162}{\left(1+3.59 \times e^{-0.00275 \times P-0.1143}\right)^{5.336}}
\end{aligned}
$$

These empirical equations, obtained by minimizing the quadratic error function, provide a good fit for the different calculated recharge rates available in Galicia-Costa and Northern Portugal versus precipitation (Fig. 5). They also allow a parameterization of recharge based on a few parameters depending on geology with a hydrogeological meaning (Eq. 15). 

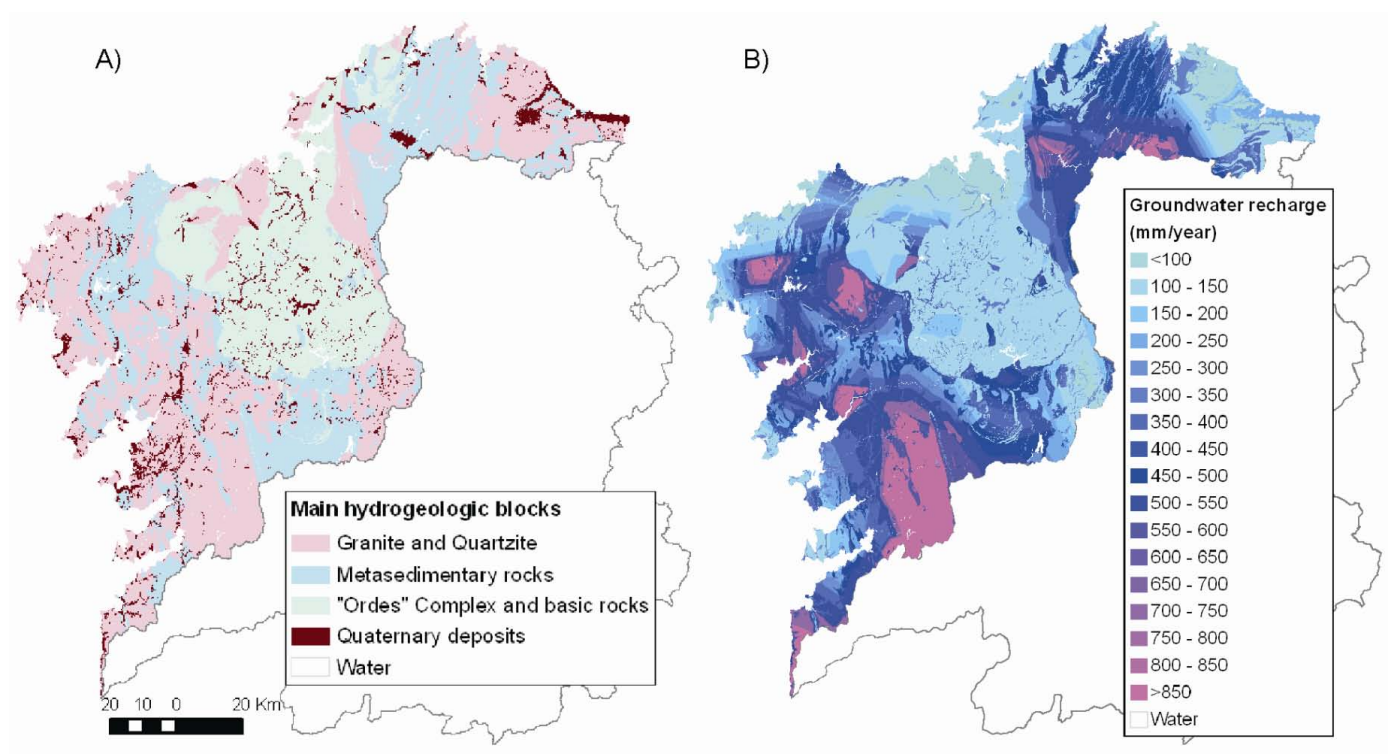

Fig. 9. Main geological units (A) considered for extrapolation of water balance models results and groundwater recharge (B) obtained for Galicia-Costa district by a GIS tool as a function of precipitation and geology.

Recharge $\left(\mathrm{mm} \mathrm{yr}^{-1}\right)=A+\frac{K-A}{\left(1+Q \times e^{-B \times P-M}\right)^{v}}$

where $K$ and $A$ represent the maximum and minimum asymptotic limits of recharge, $B$ represents the recharge growth rate, $P$ is the annual precipitation in $\mathrm{mm} \mathrm{yr}^{-1}$ and $Q, M$ and $V$ are constants dependent on the geology.

Inside the metasedimentary rock group, the schistose Complex of Ordes, along with the neighboring basic and ultrabasic rocks, present a particular set of hydrogeological characteristics. Schists from the Complex of Ordes, compared to the rest of the slates, phyllites and schists present in Galicia, are less rich in quartz and therefore weathered more easily (Fernández and Macías Vázquez, 1985). Consequently, the soils that develop over the Complex of Ordes reach greater depths. These soils also present silt-loamy textures that make them susceptible to surface crusting processes; as a result groundwater infiltration during heavy rains is significantly reduced (Paz-González et al., 2001). According the IGME (Hernández Urroz et al., 1981), the rocks that constitute the Complex of Ordes have a negligible primary permeability and a very low secondary permeability. This complex of rocks corresponds to the area with the lowest density of faults and fractures in Galicia-Costa (Fig. 1). This characteristic reduces the water storage capacity in the secondary porosity of the bedrock. For these reasons groundwater recharge rate in the Complex of Ordes is assumed to be lower than in the rest of the metasedimentary rocks. An average recharge of $8.4 \%$ of the precipitation (obtained from CMB) is assumed.
Finally, quaternary deposits represent a very low area in Galicia-Costa and the recharge coefficient for these detrital deposits is assumed to be $22 \%$ of the precipitation (Control y Geología S.A., 2005).

Figure $9 \mathrm{~b}$ shows the spatial distribution of groundwater recharge in Galicia-Costa, depending on climatic and geological factors. Comparison of this map with those obtained by CMB (Fig. 8c) shows a consistency in the results. Results indicate that the water balance method is a powerful tool in understanding the main features of recharge processes when short time steps are used and the spatial variability of components is taken into account (de Vries and Simmers, 2002).

Total groundwater resources in Galicia Costa are significant. An annual groundwater recharge of $4427 \mathrm{hm}^{3}$ was estimated for the whole district, an amount significantly higher than estimated in previous studies. The greatest groundwater recharge rates occur in southwestern granitic areas with a high annual precipitation (Fig. 9b).

Due to the large temporal and spatial variability of groundwater recharge, its short residence time, the limited storage capacity of Galician fractured bedrock aquifers, as well as the technical difficulties for its full pumping, groundwater resources are not enough for water supply to large cities; however, they are particularly suitable for water supply to small villages and scattered rural populations. According to recent statistical surveys there are almost 800000 people $(40.2 \%$ of the total population) in Galicia Costa living in villages of less than 500 people. With an average per capita water demand of 1391 day $^{-1}$ in Galicia (INE, 2009), water consumption in rural areas reaches $40.5 \mathrm{hm}^{3} \mathrm{yr}^{-1}$. This represents less than $1 \%$ of total groundwater resources, as calculated in the present paper. Therefore, the likely environmental impact 


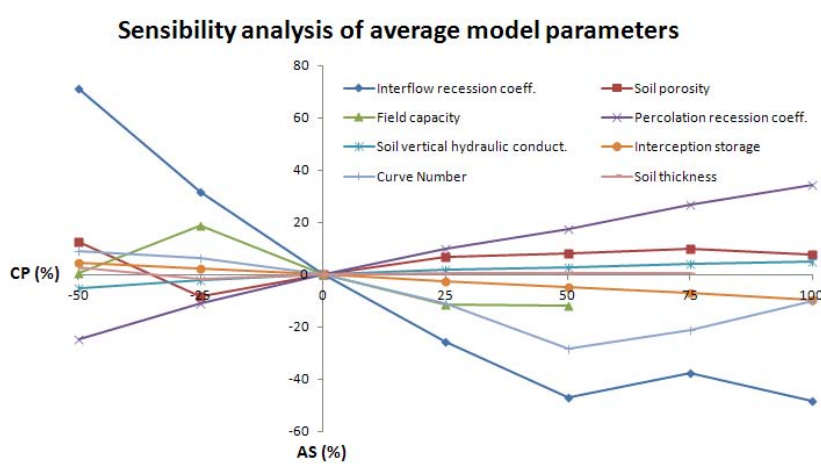

Fig. 10. Sensitivity analysis of model parameters on estimated recharge, average results for the nine pilot basins (only the eight most sensitive parameters are showed). $\mathrm{CP}$ is the relative change of a given variable or parameter and AS is the relative change in the recharge value.

derived from this use could safely be deemed negligible. This approach appears to be more sustainable than surface water-based solutions both from an ecological and economical point of view.

\section{Uncertainty and sensitivity analysis}

The estimation of groundwater recharge contains several potential sources of uncertainty related to the methodological approach used, the parameters estimation and/or the upscaling process.

Combining and comparing methods allows for the deviation of estimates provided by different techniques applied in the same hydrological zone to be known (Flint et al., 2002). Differences between punctual estimates with both methods used are lower than $7.7 \%$ (Table 4 )

The uncertainties associated with the model parameters were evaluated by computing the relative sensitivity criteria AS/CP (Eq. 16) defined by Jiménez-Martínez et al. (2010),

Relative_sensitivity : $\frac{\mathrm{AS}}{\mathrm{CP}}=\frac{\left|C_{\mathrm{s}}-C_{\mathrm{b}}\right| \times 100 / C_{\mathrm{b}}}{\left|P_{\mathrm{s}}-P_{\mathrm{b}}\right| \times 100 / P_{\mathrm{b}}}$

where $\mathrm{CP}$ is the relative change of a given variable or parameter and AS is the relative change in the output (recharge) value, $P_{\mathrm{s}}$ and $P_{\mathrm{b}}$ are variable values used for sensitivity and calibrated base runs, respectively, and $C_{\mathrm{s}}$ and $C_{\mathrm{b}}$ are output data (recharge) computed in sensitivity and calibrated base runs, respectively. When tolerable ranges allows it, the magnitude of the parameter perturbation (CP) was fixed from $-50 \%$ to $+100 \%$ with respect to the original data. Figure 10 shows the effect on the estimated recharge in a series of simulations where each parameter was modified according to a fixed perturbation while all other parameters remained at their baseline values. Only the eight most sensitive parameters are shown. The most sensitive parameters are interflow and percolation recession coefficients, curve number and field capacity. The sensitivity criteria AS/CP is lower than 0.35 for the remaining model parameters.

The main uncertainty source for recharge estimation by CMB is the lack of chloride concentration in runoff water data and the assumption of a unique concentration factor $(\mathrm{Fc})$ for the whole of Galicia-Costa. A sensitivity analysis of $\mathrm{Fc}$ on recharge estimation was carried out by changing $\mathrm{Fc}$ in the range of values observed in Northern Spain from 1 to 1.5 (Alcalá, 2005). A high sensitivity was observed with an average variation of recharge estimates from $-16.67 \%$ to $32.35 \%$ with respect to the baseline obtained with $\mathrm{Fc}=1.17$.

\section{Summary and conclusions}

A relation among groundwater recharge and total precipitation according to a logistic curve was found for both of the two main geologies in Galicia-Costa. These curves satisfactorily reproduced the estimated recharge values in several pilot basins along the study area during different hydrological years that includes a range of climatic conditions. Notable differences are observed in hydrogeological behavior of granite and metasedimentary rocks despite both are fractured crystalline rocks. Groundwater recharge is greater in schists than in granites when precipitation is moderate. However, schists present a lower storage capacity that limits recharge when annual precipitation is higher, whereas recharge in granites continues to rise at a high growth rate. Therefore, granite formations are more interesting for groundwater purposes in areas of high precipitation. It is remarkable that precipitation higher than $1800-2000 \mathrm{~mm} \mathrm{yr}^{-1}$ barely contributes to a recharge increase; as it fills the storage capacity in both rock types, the excess water is forced to flow as runoff and interflow.

Total groundwater resources in Galicia-Costa were estimated at $4427 \mathrm{hm}^{3} \mathrm{yr}^{-1}$, significantly higher than in previous studies.

Main uncertainties in model recharge estimations are associated with the large number of used parameters. However, only a few parameters (i.e., interflow and percolation recession coefficients, curve number, and field capacity) present high sensitivity on recharge estimations. Since modeled discharge and water table levels strongly depend on these parameters too, an accurate daily calibration of the models is required for a correct estimation of these sensitive parameters.

Uncertainty of the recharge estimation using the CMB method is mainly related to the assumed $\mathrm{Fc}$ value. Because there is a large fraction of the water balance that corresponds to runoff (overland plus interflow), the chloride concentration measures in the runoff are necessary to accurately estimate recharge. Therefore, current estimates with a fixed Fc must only be considered as values of orientation. 
Groundwater recharge shows a highly unequal spatial distribution in Galicia-Costa depending on the climatic and geologic factors. For example, maximum recharge is found in mountainous areas in the southwest where high annual precipitation and fractured granitic bedrock are present.

The large temporal variability of groundwater recharge, the short residence time of groundwater, the limited storage capacity and the small size of Galician aquifers on fractured bedrock make the exploitation of this resource difficult for large pumping centers. However, groundwater resources are particularly suitable for water supply to small villages and scattered rural populations by means of multiple small pumping centers. $40 \%$ of the total Galicia-Costa population could be supplied by groundwater using less than $1 \%$ of its total resources, with a minimum environmental impact.

Acknowledgements. This work has been co-funded by Augas de Galicia and the Galician government Xunta de Galicia, within the framework of research project INCITE09 203072 PR and by the European Regional Development Fund (ERDF). The first author has been granted a F.P.U. fellowship by the Spanish Ministry of Education. The authors would like to thank the comments from the editor and two anonymous reviewers that undoubtedly improved the quality of this paper.

Edited by: I. Neuweiler

\section{References}

Alcalá, F. J.: Recarga a los acuíferos españoles mediante balance hidrogeoquímico [Recharge in Spanish aquifers by means of hydrogeochemical balance] thesis/masters, Universidad Politécnica de Cataluña, available at: http://www.tdx.cat/handle/10803/6240;jsessionid= A4C27AD702E6C20580EED864246D3A1C.tdx2 (last access: 2 December 2011), 2005.

Alcalá, F. J. and Custodio, E.: Atmospheric chloride deposition in continental Spain, Hydrol. Process., 22, 3636-3650, 2008a.

Alcalá, F. J. and Custodio, E.: Flujo de cloruro por la escorrentía directa en España [Chloride flux by direct runoff in Spain], Ingeniería del agua, 15, 5-11, avaliable at: http://upcommons. upc.edu/revistes/bitstream/2099/10708/1/I-V15N1.pdf (last access: 7 December 2011), 2008b.

Alencoão, A., Pacheco, F., and Ferreira, M. P.: A bacia hidrográfica do rio Corgo (NE Portugal): escoamento subterrâneo e parámetros influentes [The basin of river Corgo (NE Portugal): groundwater recharge and involved parameters], in: Las Aguas Subterráneas en el Noroeste de la Península Ibérica, edited by: Samper, J., Leitão, T., Fernández, L., and Ribeiro, L., IGME, Madrid, Spain, 173-182, 2000.

Allen, R. G., Pereira, L. S., Raes, D., and Smith, M.: Crop evapotranspiration - Guidelines for computing crop water requirements - FAO Irrigation and drainage paper 56, FAO, Rome, 1998.

Allison, G. B. and Hughes, M. W.: The use of natural tracers as indicators of soil-water movement in a temperate semi-arid region, J. Hydrol., 60, 157-173, 1983.
Banks, D., Gundersen, P., Gustafson, G., Mäkelä, J., and Morland, G.: Regional similarities in the distributions of well yield from crystalline rocks in Fennoscandia, Norg. Geol. Unders. B., 450, 33-47, 2010.

Barral, M. T., Ariasa, M., and Guérif, J.: Effects of iron and organic matter on the porosity and structural stability of soil aggregates, Soil Till. Res., 46, 261-272, 1998.

Bradford, R. B., Ragab, R., Crooks, S. M., Bouraoui, F., and Peters, E.: Simplicity versus complexity in modelling groundwater recharge in Chalk catchments, Hydrol. Earth Syst. Sci., 6, 927937, doi:10.5194/hess-6-927-2002, 2002.

Candela, L., von Igel, W., Javier Elorza, F., and Aronica, G.: Impact assessment of combined climate and management scenarios on groundwater resources and associated wetland (Majorca, Spain), J. Hydrol, 376, 510-527, 2009.

Carballeira, A., Devesa, C., Retuerto, R., and Santillán, E.: Bioclimatología de Galicia [Bioclimatology of Galicia], Fundación Pedro Barrié de la Maza, A Coruña, Spain, 1983.

Carrica, J. C.: Natural recharge evaluation of the aquifer in the upper Arroyo Napostá Grande basin, province of Buenos Aires, Revista de la Asociación Geológica Argentina, 59, 281-290, 2004.

Castañeda, C. and García-Vera, M. A.: Water balance in the playalakes of an arid environment, Monegros, NE Spain, Hydrogeol. J., 16, 87-102, 2008.

Church, R.: Sensitivity testing of the methodology for groundwater recharge assessment, Report project WFD31, Sniffer, Edinburgh, 37 pp., 2004.

Control y Geología S.A.: Estudio de caracterización de las masas de agua subterránea y el diseño de una red de control de las aguas subterráneas [Characterization of groundwater bodies and design of a monitoring network of groundwater], Expediente: EC01404AT, Santiago de Compostela, Spain, 2005.

Cook, P. and Böhlke, J.: Determining timescales for groundwater flow and solute transport, Environmental tracers in subsurface hydrology, edited by: Cook, P. and Herczeg, A. L., Kluwer Academic Publishers, Boston, 1-30, 2000.

Custodio, E.: Evaluación de la recarga por la lluvia mediante métodos ambientales químicos, isotópicos y térmicos [Evaluation of rainfall recharge by means of chemical, isotopic and thermal environmental methods], in: La Evaluación de la Recarga a los Acuíferos en la Planificación Hidrológica, edited by: Custodio, E., Llamas, M. R., and Samper, J., IGME, Las Palmas de Gran Canaria-Madrid, Spain, 83-110, 1997.

Da Silva Lima, A. and Oliveira da Silva, M.: Estimativa da recarga em terrenos graníticos: uma discussão [Recharge estimation in granitic terrains: a discussion], in: Las Aguas Subterráneas en el Noroeste de la Península Ibérica, edidet by: Samper, J., Leitão, T., Fernández, L., and Ribeiro, L., IGME, Madrid, Spain, 183190, 2000.

Dafonte, J. and Raposo, J. R.: Estudio del potencial hidrogeológico de las fincas de Bosques Naturales en Arzúa y Boimorto para el potencial aprovechamiento de las aguas subterráneas [Hydrogeological survey in the plots of Bosques Naturales for potential groundwater use], unpublished technical report, 2009.

de Vries, J. J. and Simmers, I.: Groundwater recharge: an overview of processes and challenges, Hydrogeol. J., 10, 5-17, 2002.

Environment Agency: The North Cornwall Catchment Abstraction Management Strategy, 2005. 
Eriksson, E. and Khunakasem, V.: Chloride concentration in groundwater, recharge rate and rate of deposition of chloride in the Israel Coastal Plain, J. Hydrol., 7, 178-197, 1969.

Espinha-Marques, J., Samper, J., Pisani, B., Alvares, D., Carvalho, J. M., Chaminé, H. I., Marques, J. M., Vieira, G. T., Mora, C., and Sodré-Borges, F.: Evaluation of water resources in a highmountain basin in Serra da Estrela, Central Portugal, using a semi-distributed hydrological model, Environ. Earth Sci., 62, 1219-1234, 2011.

Estrela, T., Cabezas Calvo-Rubio, F., and Estrada Lorenzo, F.: La evaluación de los recursos hídricos en el Libro Blanco del Agua en España [The assessment of water resources in the White Book of Water in Spain], Ingeniería del agua, 6, 125-138, 1999.

European Commission: Directive of the European Parliament and of the Council 2000/60/EC establishing a framework for Community action in the field of water policy, CELEX-EUR Official Journal L, 327, 1-72, 2000.

Fernández, M. and Macías Vázquez, F.: Contribución a la caracterización químico-mineralógica de los esquistos del "Complejo de Ordes" [Contribution to chemical-mineralogical characterization of schists from the "Complex of Ordes"], Cuad. Lab. Xe., 9, 469-494, 1985.

Fernández-Sanjurjo, M. J., Vega, V. F., and García-Rodeja, E.: Atmospheric deposition and ionic concentration in soils under pine and deciduous forests in the river Sor catchment (Galicia, NW Spain), Sci. Total Environ., 204, 125-134, 1997.

Flint, A. L., Flint, L. E., Kwicklis, E. M., Fabryka-Martin, J. T., and Bodvarsson, G. S.: Estimating recharge at Yucca Mountain, Nevada, USA: comparison of methods, Hydrogeol. J., 10, 180204, 2002.

Fornés, J. M., de la Hera, Á., and Llamas, M. R.: The silent revolution in groundwater intensive use and its influence in Spain, Water Policy, 7, 253-268, 2005.

Fouépé Takounjou, A., Ndam Ngoupayou, J. R., Riotte, J., Takem, G. E., Mafany, G., Maréchal, J. C., and Ekodeck, G. E.: Estimation of groundwater recharge of shallow aquifer on humid environment in Yaounde, Cameroon using hybrid water-fluctuation and hydrochemistry methods, Env. Earth Sciences, 64, 107-118, 2010.

Franco Bastianelli, S.: Estudio sobre las posibles causas de los daños en las edificaciones de un área del casco urbano de Ponteceso [Study on possible causes of damage to buildings in an urban area of Ponteceso] Technical report, INGEBAIRES, Vigo, available at: http://www.ponteceso.net/informe/informefinal.pdf (last access: 18 March 2012), 2010.

García-Rodeja, E., Fernández-Sanjurjo, M. J., and Fernández-Vega, V.: Input-output ion fluxes in the River Sor catchment (Galicia, NW Spain), Chemosphere, 36, 1107-1112, 1998.

Garcia-Santos, G. and Marzol, V.: Groundwater recharge in a mountain cloud laurel forest at the Garajonay National Park (Spain), Geophys. Res. Abstr., EGU2005-A-00942, EGU General Assembly 2005, Vienna, Austria, 2005.

Gómez Rey, M., De Anta, C., and María, R.: Datos para el desarrollo de una red integrada de seguimiento de la calidad de los suelos en Galicia (N. O de España): Balances geoquímicos en suelos forestales (Pinus radiata). 1. Aportes de elementos por disposición atmosférica y hojarasca [Data for the development of an integrated monitoring network of soil quality in Galicia (NW Spain)], Edafología, 9, 181-196, 2002.
González-Arias, A., Amezaga, I., Echeandía, A., and Onaindia, M.: Buffering capacity through cation leaching of Pinus radiata D. Don canopy, Plant Ecol., 149, 23-42, 2000.

Guan, H., Love, A. J., Simmons, C. T., Makhnin, O., and Kayaalp, A. S.: Factors influencing chloride deposition in a coastal hilly area and application to chloride deposition mapping, Hydrol. Earth Syst. Sci., 14, 801-813, doi:10.5194/hess-14-801-2010, 2010.

Healy, R. W., Gray, J. R., de Vries, M. P., and Mills, P. C.: Water balance at a low-level radioactive disposal site, J. Am. Water Resour. As., 25, 381-390, 1989.

Hernández Urroz, J., Divar Rodríguez, J., Diez Balda, M. A., and Martínez Catalán, J. R.: Mapa Geológico Nacional de España, Hoja 70, Órdenes [National Geologic Map of Spain, Sheet 70 corresponding to Órdenes], 1:50000, 1981.

Hernandez-Mora, N., Llamas, M., and Martínez Cortina, L.: Misconceptions in aquifer overexploitation: implications for water policy in Southern Europe, Agricultural use of groundwater. Towards integration between agricultural policy and water resources management, Kluwer Academic Publishers, 107-125, 2001.

Horton, R. E.: Rainfall interception, Mon. Weather Rev., 47, 603623, 1919.

IGME: Cartografía Geológica Continua Digital de España (GEODE) [Continuous Digital Geological Map of Spain], 1:50000, 2004.

INE: Encuesta sobre el suministro y saneamiento del agua en el año 2009 [Survey on water supply and sanitation in 2009], available at: www.ine.es/prensa/np659.pdf (last access: 15 December 2011), 2009.

Jiménez-Martínez, J., Candela, L., Molinero, J., and Tamoh, K.: Groundwater recharge in irrigated semi-arid areas: quantitative hydrological modelling and sensitivity analysis, Hydrogeol. J., 18, 1811-1824, 2010.

Knutsson, G.: Hydrogeology in the Nordic countries, Episodes, 31, $1-7,2008$.

Krásný, J.: Quantitative hardrock hydrogeology in a regional scale, Norg. Geol. Unders. B., 439, 7-14, 2002.

Krause, P., Boyle, D., and Bäse, F.: Comparison of different efficiency criteria for hydrological model assessment, Adv. Geosci., 5, 89-97, 2005, http://www.adv-geosci.net/5/89/2005/.

Lima, A. S. and Silva, M. O.: Estudo hidrogeológico dos granitóides da região de Braga (NW de Portugal) [Hydrogeological study of granites in Braga region (NW of Portugal)], in: Memórias no. 4. Museu e Laboratório Mineralógico e Geológico da Faculdade de Ciencias da Universidade do Porto, edited by: Borges, F. S. and Marques, M. M., Porto, Portugal, 461-465, 1995.

Llamas, M. R. and Martínez-Santos, P.: Intensive groundwater use: Silent revolution and potential source of social conflicts, J. Water Res. Pl.-ASCE, 131, 337-341, 2005.

López, A., Blázquez, R., Torres, M. M., Alvarez, A., Vidal, M., and Roquero, C.: Efecto del riego con soluciones de productos encalantes sobre la conductividad hidraulica de suelos acidos de reducida permeabilidad [Effect of irrigation with solutions of liming products on hydraulic conductivity of acid soils with low permeability], in: 16th World Congress of Soil Science, Montpellier, France, 1998. 
Marques da Costa, A.: Estado actual do conhecimento das águas subterrâneas no norte de Portugal [Current state of knowledge of groundwater in northern Portugal], in: Las Aguas Subterráneas en el Noroeste de la Península Ibérica, edited by: Samper, J., Leitão, T., Fernández, L., and Ribeiro, L., IGME, Madrid, 129146, 2000.

Martin, N. and van de Giesen, N.: Spatial distribution of groundwater production and development potential in the Volta River basin of Ghana and Burkina Faso, Water Int., 30, 239-249, 2005.

Martínez, A. I., Molinero, J., Dafonte, J., and Galíndez, J. M.: Toma de datos y modelización hidrogeológica de un acuífero kárstico de alta montaña (Valle de la Respina, León) [Data gathering and hydrogeological modeling of a high-mountain karst aquifer (Respina Valley, León)], in: From data gathering and groundwater modelling to integratd management, edited by: Sánchez-Vila, X., del Carmen Cabrera, M., Santana, M. C. C., and Valverde, M., IGME, Madrid, 459-464, 2006.

Martins Carbalho, J., Plasência, N., Chaminé, H. I., Rodrigues, B. C., Guerner Dias, A., and Antunes da Silva, M.: Recursos hídricos subterâneos em formaçoes cristalinas do norte de Portugal [Groundwater resources in crystalline bedrock in North Portugal], in: Las Aguas Subterráneas en el Noroeste de la Península Ibérica, edited by: Samper, J., Leitão, T., Fernández, L., and Ribeiro, L., IGME, Madrid, 163-172, 2000.

Massuel, S., George, B., Gauer, A., and Nune, R.: Groundwater modeling for sustainable resource management in the Musi catchment, India, in: Proceedings of the International Congress on Modelling and Simulation, Christchurch, New Zealand, 1013 December 2007, 1425-1439, 2007.

McCartney, M. P. and Houghton-Carr, H. A.: An Assessment of Groundwater Recharge on the Channel Island of Jersey, Water Environ. J., 12, 445-451, 1998.

Memon, B.: Quantitative analysis of springs, Environ. Geol., 26, 111-120, 1995.

Mendes Oliveira, M. and Lobo Ferreira, J. P. C.: Estudo da recarga de águas subterrâneas em áreas do maciço antigo do norte de Portugal continental [Study of groundwater recharge in areas of the Hercynian Massif in North Portugal], in: Las Aguas Subterráneas en el Noroeste de la Península Ibérica, edited by: Samper, J., Leitão, T., Fernández, L., and Ribeiro, L., IGME, Madrid, 191198, 2000.

Molinero Huguet, J., Soriano Hoyuelos, G., and Samper Calvete, J.: Calidad y contaminación de las aguas subterráneas en Galicia: situación actual y estudio de detalle en la cuenca del Valiñas [Quality and contamination of groundwater in Galicia: present situation and detailed study in the Valiñas catchment], in: Jornadas sobre la contaminación de las aguas subterráneas: un problema pendiente, edited by: Samper, J., Sahuquillo, A., Capilla, J. E., and Gómez Hernández, J. J., AIH-GE, Valencia, 255-260, 1998.

Murphy, E. M., Ginn, T. R., and Phillips, J. L.: Geochemical estimates of paleorecharge in the Pasco Basin: Evaluation of the chloride mass balance technique, Water Resour. Res., 32, 28532868, 1996.

Nash, J. E. and Sutcliffe, J.: River flow forecasting through conceptual models part I - A discussion of principles, J. Hydrol., 10, 282-290, 1970.

Navarro Alvargonzález, A., Fernández Uría, A., and Doblas Domínguez, J. G.: Las aguas subterráneas en España: Estudio de síntesis [Groundwater in Spain: Study of synthesis], Instituto Tecnológico Geominero de España, Madrid, 1993.

Neal, C. and Kirchner, J. W.: Sodium and chloride levels in rainfall, mist, streamwater and groundwater at the Plynlimon catchments, mid-Wales: inferences on hydrological and chemical controls, Hydrol. Earth Syst. Sci., 4, 295-310, doi:10.5194/hess-4295-2000, 2000.

Paz-González, A., Thonon, I., Bertolani, F. C., Taboada-Castro, M. M., Vidal-Vázquez, E., and Dafonte, J. D.: Variabilidad espacial de la infiltración en una ladera determinada con permeámetro de Guelph e infiltrómetro de tensión [Spatial variability of water infiltration in a fixed hillslope with Guelph permeameter and tension infiltrometer], in: Temas de investigación en la zona no saturada, edited by: López Rodríguez, J. J. and Quemada SaézBadillos, M., Universidad Pública de Navarra, Pamplona, Spain, 51-60, 2001.

Paz-González, A., Díaz-Fierros Viqueira, F., Soto González, B., and López Periago, E.: Uso de un modelo basado en eventos para evaluar la conductividad hidráulica en una cuenca de pequeñas dimensiones [Using an event-based model to evaluate the hydraulic conductivity in a small basin], in: Estudios de la Zona No Saturada del Suelo. Actas de las VI jornadas sobre investigacion de la zona no saturada del suelo, edited by: Álvarez-Benedí, J. and Marinero, P., Instituto Tecnológico Agrario de Castilla y León, 313-318, 2003.

Pereira, M. R.: Quantificação da recarga subterrânea em rochas fracturadas da bacia hidrográfica do Tua [Quantification of groundwater recharge on fractured rocks in river Tua basin], in: Las Aguas Subterráneas en el Noroeste de la Península Ibérica, edited by: Samper, J., Leitão, T., Fernández, L., and Ribeiro, L., IGME, Madrid, 155-162, 2000.

Prada-Sanchez, J., Garcia-Jurado, I., Gonzalez-Manteiga, W., Fiestras-Janeiro, M., Espada-Rios, M., and Lucas-Dominguez, T.: Multivariate statistical analysis of precipitation chemistry in northwestern Spain, Water Air Soil Poll., 69, 37-55, 1993.

Press, W., Flannery, B., Teukolsky, S., and Vetterling, W.: Numerical Recipes in Pascal, Cambridge, 1989.

Prych, E. A.: Using chloride and chlorine-36 as soil-water tracers to estimate deep percolation at selected locations on the US Department of Energy Hanford Site, Washington, US Geological Survey, 1998.

Raposo, J. R., Molinero, J., and Dafonte, J.: Quantitative evaluation of hydrogeological impact produced by tunnel construction using water balance models, Eng. Geol., 116, 323-332, 2010.

Robins, N. S.: Regional hydrogeological assessment of Wales, in: Urban geology in Wales, edited by: Bassett, M. G., Boulton, H., and Nicol, D., National Museum of Wales, Cardiff, Wales, 141150, 2009.

Robins, N. S. and Misstear, B. D. R.: Groundwater in the Celtic regions, Geol. Soc. Spec. Publ., 182, 5-17, 2000.

Robins, N. S. and Smedley, P. L.: The Jersey groundwater study, British Geological Survey Research Report RR/98/5, 48 pp., 1998.

Robins, N. S., Griffiths, K. J., Merrin, P. D., and Darling, W. G.: Sustainable groundwater resources in a hard-rock island aquifer - the Channel Island of Guernsey, Geol. Soc. Spec. Publ., 193, 121-132, 2002.

Rouxel, M., Molenat, J., Ruiz, L., Legout, C., Faucheux, M., and Gascuel-Odoux, C.: Seasonal and spatial variation in groundwa- 
ter quality along the hillslope of an agricultural research catchment (Western France), Hydrol. Process., 25, 831-841, 2011.

Rodríguez Blanco, M., Taboada Castro, M. M., and Taboada Castro, M. T.: Caracterización hidroquímica de un pequeño manantial del macizo granítico de A Coruña (NW España) [Hydrochemical characterization of a small spring in the granite massif of A Coruña (NW Spain)], Cuad. Lab. Xe., 28, 285-300, 2003.

Romay, D. and Gañete, M.: Las comunidades de usuarios de agua como ejemplo de autoabastecimiento en las cuencas de Galicia-Costa [The water users communities as an example of self-sufficiency in Galicia-Costa], in: Las aguas subterráneas en España ante las directivas europeas: Retos y perspectivas, edited by: Molinero, J., Ortuño, F., Valverde, M., and Lambán, L. J., IGME, Madrid, 239-245, 2007.

Rosenthal, E.: Chemical composition of rainfall and groundwater in recharge areas of the Bet Shean-Harod multiple aquifer system, Israel, J. Hydrol., 89, 329-352, 1987.

Sami, K. and Hughes, D.: A comparison of recharge estimates to a fractured sedimentary aquifer in South Africa from a chloride mass balance and an integrated surface-subsurface model, J. Hydrol., 179, 111-136, 1996.

Samper, J.: Aguas subterráneas y medio ambiente en Galicia [Groundwater and environment in Galicia], in: Reflexiones sobre el medio ambiente en Galicia, edited by: Casares, J. J., Consellería de Medio Ambiente, Xunta de Galicia, Santiago de Compostela, 231-249, 2003.

Samper, J. and Pisani, B.: Aquifer recharge evaluation by a combination of soil water balance and groundwater flow models, in: Estudios en la Zona no Saturada del Suelo Volumen IX, edited by: Silva Rojas, O. and Carrera Ramírez, J., Barcelona, Spain, 2009.

Samper, J., Soriano, G., and Molinero, J.: Las aguas subterráneas en Galicia: resultados en la cuenca piloto del río Valiñas [Groundwater in Galicia: results from pilot basin of river Valiñas], in: Hydrogeology of hard rocks, Some experiences from Iberian Peninsula and Bohemian Massif, edited by: Yélamos, J., and Villarroya, F., AIH-GE, Madrid, 149-158, 1997.

Samper, J., Huguet, L., Ares, J., and García-Vera, M.: Modelos interactivos de balance hidrológico [Interactive models of water balance], in: Estudios de la Zona No Saturada del Suelo, edited by: Muñoz Carpena, R., Ritter, A., and Tascón, C., ICIA, Tenerife, 187-193, 1999.

Samper, J., Huguet, L., Ares, J., and García-Vera, M. A.: Manual del usuario del programa VISUAL BALAN V. 2.0: Código interactivo para la realización de balances hidrológicos y la estimación de la recarga [User Guide of VISUAL BALAN V.2.0: Interactive code for conducting water balance and recharge estimation], Enresa, Civil Engineering School of A Coruña, Spain, 2005.

Samper, J., Bonilla, M., Zheng, L., and Yang, C.: Evaluación del impacto de los túneles en el territorio y el medio ambiente en Galicia [Assessing the impact of the tunnels in the territory and the environment in Galicia], in: Proceedings of III Congreso de ingeniería civil, territorio y medio ambiente: "Agua, Biodiversidad e Ingeniería”, 25-27 October, Zaragoza, 2006.

Sanford, W.: Recharge and groundwater models: an overview, Hydrogeol. J., 10, 110-120, 2002.

Scanlon, B. R., Healy, R. W., and Cook, P. G.: Choosing appropriate techniques for quantifying groundwater recharge, Hydrogeol. J., 10, 18-39, 2002.
Sena, C. and Molinero, J.: Water Resources Assessment and Hydrogeological Modelling as a Tool for the Feasibility Study of a Closure Plan for an Open Pit Mine (La Respina Mine, Spain), Mine Water and the Environment, 28, 94-101, 2009.

Sequeira Braga, M. A., Paquet, H., and Begonha, A.: Weathering of granites in a temperate climate (NW Portugal): granitic saprolites and arenization, Catena, 49, 41-56, 2002.

Sharma, M. L.: Groundwater recharge, Balkema Rotterdam, 1989.

Silva, B., Rivas, T., García-Rodeja, E., and Prieto, B.: Distribution of ions of marine origin in Galicia (NW Spain) as a function of distance from the sea, Atmos. Environ., 41, 4396-4407, 2007.

Soil Conservation Service: Urban hydrology for small watersheds, Technical release 55, US Department of Agriculture, 1986

Sophocleous, M. A.: Combining the soilwater balance and waterlevel fluctuation methods to estimate natural groundwater recharge: practical aspects, J. Hydrol., 124, 229-241, 1991.

Soriano, G. and Samper, J.: Hidrogeología de una pequeña cuenca piloto en medios graníticos: Cuenca del Valiñas (A Coruña) [Hydrogeology of a small pilot basin on granitic terrain: Valiñas basin (A Coruña)], in: Las Aguas Subterráneas en el Noroeste de la Península Ibérica, edited by: Samper, J., Leitão, T., Fernández, L., and Ribeiro, L., IGME, Madrid, 73-82, 2000.

Sukhija, B. S., Nagabhushanam, P., and Reddy, D. V.: Groundwater recharge in semi-arid regions of India: An overview of results obtained using tracers, Hydrogeol. J., 4, 50-71, 1996.

Vázquez, A., Costoya, M., Peña, R. M., García, S., and Herrero, C.: A rainwater quality monitoring network: a preliminary study of the composition of rainwater in Galicia (NW Spain), Chemosphere, 51, 375-386, 2003.

Weinzettel, P., Usunoff, E., Vives, L., Bocanegra, E., Hernández, M., and Usunoff, E.: Groundwater recharge estimations from studies of the unsaturated zone, edited by: Bocanegra, E., Martínez, D., and Massone, H., Balkema Publishers Londres, 2002.

Wendland, F., Blum, A., Coetsiers, M., Gorova, R., Griffioen, J., Grima, J., Hinsby, K., Kunkel, R., Marandi, A., Melo, T., Panagopoulos, A., Pauwels, H., Ruisi, M., Traversa, P., Vermooten, J. S. A., and Walraevens, K.: European aquifer typology: a practical framework for an overview of major groundwater composition at European scale, Environ. Geol., 55, 77-85, 2008.

Wilson, I. R.: Kaolin deposits of Western Iberia, Proc. Ussher., 9, 214-217, 1998.

Winter, T. C.: The concept of hydrologic landscapes, J. Am. Water Resour. As., 37, 335-349, 2001.

Wood, W. W. and Sanford, W. E.: Chemical and isotopic methods for quantifying ground-water recharge in a regional, semiarid environment, Ground Water, 33, 458-468, 1995.

World Meteorological Organization: Manual on stream gauging, Operational Hydrology, WMO No. 519, Geneve, 1980.

Xunta de Galicia: Estudio de recursos de agua subterránea en Galicia [Study of groundwater resources in Galicia], COTOP, Santiago de Compostela, Spain, 1991.

Xunta de Galicia: Plan Hidrológico de Galicia Costa [Hydrological Plan of Galicia-Costa], Real Decreto 103/2003, 24 January, 2003.

Xunta de Galicia: Propuesta de Plan Hidrológico de Galicia Costa [Proposal for Hydrological Plan of Galicia-Costa], 2011. 